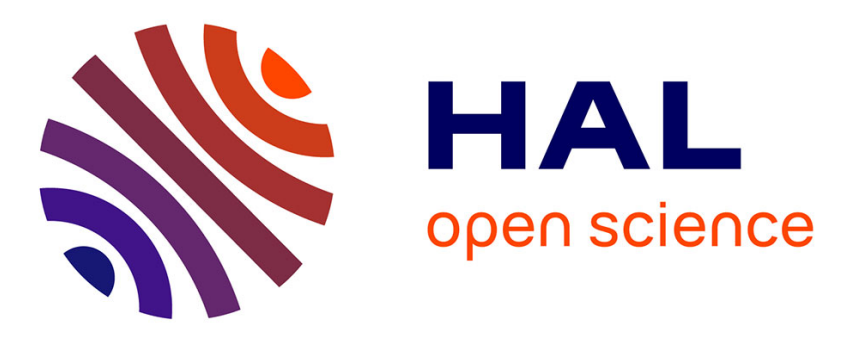

\title{
Implementation context and science-policy interfaces: Implications for the economic valuation of ecosystem services
}

\author{
Marcus Kieslich, Jean-Michel A Salles
}

\section{- To cite this version:}

Marcus Kieslich, Jean-Michel A Salles. Implementation context and science-policy interfaces: Implications for the economic valuation of ecosystem services. Ecological Economics, 2021, pp.106857. 10.1016/j.ecolecon.2020.106857 . hal-02964325

\section{HAL Id: hal-02964325 \\ https://hal.science/hal-02964325}

Submitted on 12 Oct 2020

HAL is a multi-disciplinary open access archive for the deposit and dissemination of scientific research documents, whether they are published or not. The documents may come from teaching and research institutions in France or abroad, or from public or private research centers.
L'archive ouverte pluridisciplinaire HAL, est destinée au dépôt et à la diffusion de documents scientifiques de niveau recherche, publiés ou non, émanant des établissements d'enseignement et de recherche français ou étrangers, des laboratoires publics ou privés. 


\title{
Implementation Context and Science-Policy Interfaces: Implications for the Economic Valuation of Ecosystem Services
}

\author{
Marcus Kieslich $^{\mathrm{a} 1}$, Jean-Michel Salles ${ }^{\mathrm{a}}$ \\ a. CEE-M, Univ Montpellier, CNRS, INRAE, Montpellier SupAgro, Montpellier, France \\ DOI: $10.1016 /$ j.ecolecon.2020.106857
}

Highlights:

- A review of content analyses assesses the implementation gap of ecosystem services

- Science-policy interfaces and transdisciplinarity can enhance knowledge transfer

- Better consideration of conceptual findings from implementation research is needed

- Ecosystem service valuation should consider needs of implementing actors

- Using complementarities of valuation methods contributes to this consideration

\begin{abstract}
Economic valuation has been presented as an important tool for enhancing the consideration of ecosystem services (ES) in decision-making. Recent literature provides evidence that an implementation gap between theoretical findings, consideration in the policy sphere, and measurable action in practice persists. Our paper aims to contribute to its closure. First, we assess why this gap exists by reviewing the literature on how the ES concept is adopted in policy documents and the legal system. Secondly, we present tools and structures that enhance better information transfer from valuations among actors in order to achieve transdisciplinary collaboration. Therefore, this article complements literature on science-policy interfaces (SPI) with elements from implementation research. It shows that SPIs are beneficial for different implementation contexts. Thirdly, we analyze case studies that reveal how ES valuation (ESV) could integrate the needs of various actors to get relevant to decision-makers and practitioners. We find that opportunities of different implementation contexts are not sufficiently accounted for in the
\end{abstract}

1 Corresponding author at: CEE-M, 2 place Pierre Viala, 34060 Montpellier cedex 2, France Mails : marcus.kieslich@umontpellier.fr (M. Kieslich), jean-michel.salles@umontpellier.fr (J.M. Salles) Declarations of interests: none. 
design of ESV. This could be achieved by combining traditional monetary valuation with deliberative techniques whose capacities to communicate and transfer information varies with implementation contexts. Exploiting this complementarity will help researchers, decision-makers and practitioners to close the implementation gap.

Keywords: Ecosystem Services Valuation, Deliberative Valuation, Implementation Research, Science-Policy Interface, Decision-Making, Implementation Gap

\section{Introduction}

The Ecosystem Services (ES) concept has become an important tool to support the integration of environmental needs in public policy (Daily et al, 2009; Guerry et al, 2015; Oudenhoven et al, 2018). Relevant information, maps, classifications and scenarios are used in order to enhance the process of decision-making to include environmental stakes in their choices (Polasky et al, 2015; Schirpke et al, 2017; Falk et al, 2018). The Ecosystem Service Valuation (ESV) can help highlight effects on human well-being (Salles, 2011), achieve mainstreaming ES in public decision-making (Constanza et al, 1997; Su and Peng, 2018) and information transfer (DeGroot et al, 2012; Wegner and Pascual, 2011). Although a growing literature exists on the importance of ESV, Laurans et al (2013) raised the issue of the effective use of ES valuation in decision-making; the answer being that this use remains limited. They pointed out the existence of a literature gap concerning this issue: "The common rule is to present an economic valuation, then suggest that it [may] be used for decision-making, but without this use being either explicited or contextualized, and without concrete examples being provided nor analyzed" (Laurans et al, 2013; p. 217).

As a possible interpretation the authors suggest that researchers are not really interested in the use of Ecosystem Services Valuation by practitioners in decision-making at all (Spash and Vatn, 2006; Laurans and Mermet, 2014; Olander et al, 2017). Sharing the viewpoint which is also expressed in Marre et Billé (2019), we refer here to a "demand-driven use of ESV" where valuations are not offered by scientist hoping to contribute to the overall issue. Instead, ESV is actively demanded or proposed by decision-makers, practitioners or trans- or interdisciplinary institutions. This gave rise to what some authors argue to be an "implementation gap" of ESV (Levrel et al, 2017). Our paper aims to contribute to closing this gap in four ways.

First, we attempt to figure out this "implementation gap." A significant literature about the use of 
the ES concept in policy documents (e.g. Rozas-Vasquez et al, 2018; Teixeira da Silva et al, 2018), among practitioners (Poljanec-Boric et al, 2018) and in legislation (Adaire and DiPinto, 2018; Sharon et al, 2018) has emerged recently. We provide a review of this literature in order to assess and summarize how the ES concept is applied in practice and what promotes or harms its efficient use.

Second, many necessary guidelines on how to conduct and promote results of ES research to enhance implementation among decision-makers have emerged (e.g. Fisher et al, 2009; Rosenthal et al, 2015; Olander et al, 2017). Nevertheless, the theoretical foundations of implementation research have not been sufficiently accounted for in the ES literature yet. We present this literature and link it to the existing literature about ESV. We therefore define implementation context of ES policy as a situation in which a decision about ES governance (or more general issues) has to be either enforced or assessed. This includes in particular how this process is affected by external factors such as the institutional setting, data availability, human capital, etc. In this article we will mainly focus on the institutional setting. The question here is how valuation can address the various implementation contexts and needs of science-policy interfaces (SPI). The use of several types of valuation techniques has been shown to be beneficial to account for different value dimensions (Jacobs et al, 2018). Given the current decision-making processes, how can valuation techniques evolve to meet the needs of the authorities charged with the implementation?

Third, we include institutional vehicles such as SPI that can considerably improve information transfer (Cash and Moser, 2000; Sarkki et al, 2014; Young et al, 2014) into our analysis. SPI are structures of processes aiming to use the intersection between science and policy to support decision-making by exchange, co-evolution and joint construction of knowledge (adapted from van den Hove, 2007). Based on these better-informed decisions, policy implementation affects the ES initially assessed and valued (Guerry et al, 2015). Figure 1 illustrates this "classical view" on the role of ESV within the decision-making process: Valuation is produced by researchers and expert consultants or co-produced in SPIs and delivered to the "decision-making sphere" at different scales (local, global, etc.) The latter decide on a policy by using or not using this knowledge. As illustrated, this is the step where scarce interest of the use of ESV is observed by Laurans et al (2013). The policy is applied by administrations and charged organizations (the implementation sphere) and affects the ES initially valued. 


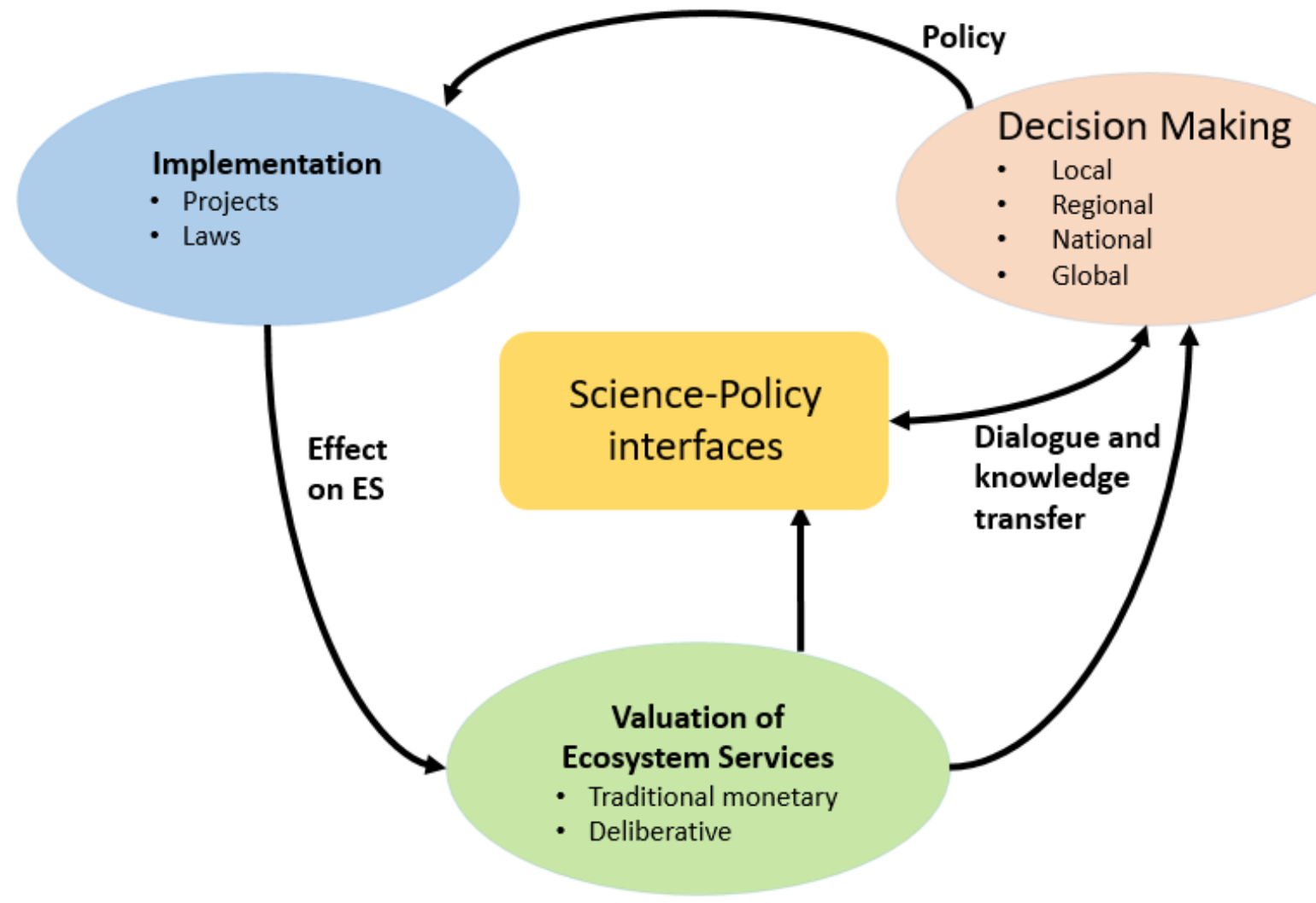

Figure 1: Classical view in the literature on the relation between the spheres of Ecosystem Services Valuation, Decision-Making and Implementation

As an example, the Economics of Ecosystems and Biodiversity (TEEB) framework which created considerable attention (although criticized from an academic point of view, Tisdell et al, 2014) for conceptualizing and standardizing ES valuation (TEEB, 2010), states in its study report for local and regional policy-makers that it is "intended to guide policy-makers in designing their own processes for appraising and considering nature's benefits" (TEEB 2010; p.7). Hence, decision-making processes are seen as having to be adapted in order to better integrate the results of valuation.

Therefore, we propose a complementary process to that one in figure 1 to be considered. Our analysis shows that the uptake of ES within policy depends - of course - on decision-making, but on implementation context as well. It recapitulates how a transdisciplinary interplay between implementation contexts, science-policy interfaces and ESV (e.g. Martin-Ortega et al, 2015) can enhance the uptake of ESV within decision-making. In consequence, this might contribute to the closure of the implementation gap. In exploring this we modify Figure 1 to illustrate the potential pivotal role of ESV and transdisciplinary research, see Figure 2.

The article is organized as follows: We firstly summarize the main findings on why the ES concept is seen as a possible vehicle to integrate ES in decision-making and how it is already integrated in 
policy documents and law (section 2). Being already broadly discussed in the literature, a short overview of science-policy interfaces follows, while focusing on implications for research on economic valuation of ES (section 3). We then introduce theoretical elements from implementation research and how transdisciplinarity connects to bottom-up and top-down implementation. Finally, we use these theoretical findings to discuss opportunities, limitations and complementarities of different valuation techniques for policy implementation by using exemplary case studies. We conclude with reflection on the role of empirical experience, SPIs in transmitting information and the role of deliberative valuation approaches in providing policy makers and practitioners with relevant information.

\section{Evidence of the Mainstreaming of the Ecosystem Services concept}

As pointed out in the Introduction, much effort is undertaken to inform decision-making about the management of ES by using economic valuation. Therefore, it is necessary to assess whether the concept of ES is well known and applied among decision-makers and practitioners. This socalled mainstreaming helps to transmit theoretical evidence into concrete action and to consider impacts of policies on Ecosystem Services (Daily et al, 2009, Maes et al, 2013). Adoption of the concept is expected to improve understanding for environmental problems and to promote sustainable solutions within local decision-making (Posner et al, 2016a). In this section we focus on how far the mainstreaming of the ES Concept got and what advantages and caveats exists (i) in policy design and public administration and (ii) in jurisdiction and law.

\subsection{Use within policy and public administration}

The following section presents drawbacks from studies dealing with the implementation of ES within policy and administration by using either content analysis of policy documents or surveys of practitioners. Table 1 presents significant articles assessing the integration of the ES concept. These articles were selected from a web search of Google Scholar using the terms "Ecosystem Services" coupled with either "Content Analysis" or "policy documents." They were complemented by papers appearing in the references of our first sample. The resulting selection covers a wide range of different policy contexts, study areas and administrative scales, ranging from local to international. Integration of ES is mostly measured by the degree of explicitness (using the term "Ecosystem Services" or near substitutes or no explicit term at all) or by the degree of detail used to describe the concept or specific services (e.g. Nordin et al, 2017). They provide consistent results on how ES are included and where policy integration of the concept is 
confronted with barriers. We identified five main issues which are addressed individually.

\section{Explicitness and Implicitness}

Nearly all papers of Table 1 report that ES are increasingly mentioned within policy context (Bouwma et al, 2017; Rozas-Vasquez et al, 2018), but often implicitly (referring generally to the role and function without using a specific term). Rarely, these benefits are called explicitly "Ecosystem Services" (or equivalently), or specific Ecosystem Services (e.g. maintenance of wildlife habitat, flood control, etc.) are mentioned. This lack of explicitness can be seen as an indicator for existing gaps in understanding within administrations and the need for clear definitions in order to diminish ambiguity (Hansen et al, 2015; Maczka et al, 2016). Accordingly, possible trade-offs among different services are more difficult to address (Rozas-Vasquez et al, 2018). These findings confirm the analysis of Kettunen et al (2014) that a solid conceptual base within policy spheres and administration exists and is growing, but not yet translated into proactive outcomes.

\section{$\underline{\text { Interdisciplinarity and Transdisciplinarity }}$}

Regarding the broad range of ways in which human well-being is affected by ES, it becomes important to resolve trade-offs and synergies across different sections and domains (Bouwma et al, 2017). Two concepts have to be distinguished: interdisciplinarity, where collaboration among several disciplines brings multiple views on the same issue, and transdisciplinarity that aims not only to cooperate, but to create a "common knowledge" among disciplines. This systematic use of the ES concept is still limited, complicating cooperation among different administrative departments and disciplines (Hatton MacDonald et al, 2014; Poljanec-Boric et al, 2018). This finding is particularly noteworthy, given that interdisciplinary communication, a common ground for dialogue among stakeholders, and awareness-rising are seen as important merits of the ES concept (Hatton MacDonald et al, 2014; Maczka et al, 2016; Lam and Conway, 2018). Possible solutions to foster this broader view could be to involve more stakeholders and strengthen transdisciplinary capacities within administrations. Research agencies and universities can play a role as knowledge brokers, notably for establishing practicable indicators and common knowledge (Hansen et al, 2015; Teixeira da Silva et al, 2018; Rozas-Vasquez et al, 2018). 


\section{Differences Among Ecosystem Services}

The consideration of ES depends on their nature: most studies examining different types find a higher recognition of regulating services than it is the case for provisioning or nonmaterial services (Maczka et al, 2016; Rozas-Vasquez et al, 2018). The latter are mostly considered in the context of tourism and recreation (Bouwma et al, 2017; Nordin et al, 2017). The same difference is identified by Lam and Conway (2018) but on different scales. At municipal level, recreation is the most frequently mentioned service whereas at regional scale regulating services appear more often. Only Hansen et al (2015) find no disparity among ES types within documents. The limited integration of nonmaterial services other than recreation and tourism is possibly due to the relatively low coverage of content analyses assessing other domains than those already closely related to ES (e.g. flood risk management, land use planning, urban planning, economic affairs, etc.) Interestingly, this retraces the same lack of less tangible nonmaterial services as is found in the ESV literature in general (see Cheng et al, 2019). The frequently observed integration of regulating services corresponds to an adaptation of the concept of ecological function (PotschinYoung et al, 2017): they represent ecological processes necessary for an ecosystem to be in condition to provide services. For economic valuation, this stimulates the debate about the correct specification of intermediate and final services (Johnston and Russell, 2011; PotschinYoung et al, 2017).

\section{Spatial Scales}

As seen above, different contexts and spatial scales are important to understand the use of the ES concept within policy documents and possible barriers for their implementation (Claret et al, 2018). Given the diverse valuation methods, many studies are not easily adaptable to local contexts or to be aggregated or disaggregated in order to fit into administrative borders of practitioners (Hatton MacDonald et al, 2014; Teixeira da Silva et al, 2018). Moreover, this limits the possibility to link ES to their service providing units (SPU), which would be necessary for environmental-economic accounting (Lam and Conway, 2018; European Commission, 2013).

The inclusion of ES within the policy sphere depends on the spatial scale as well. In interviews with practitioners, the latter seem to infer particular importance to regional and national scales (Poljanec-Boric et al, 2018). Content analysis confirms this finding, by acknowledging that regional and national scales are connecting local to global management and help to enforce a top-down application of higher-scaled policy goals (Maczka et al, 2016; Rozas-Vasquez et al, 2018). For EU 
policy, this top-down application depends on the type of policy: regulations are difficult to be reframed and adapted to local and regional environmental contexts (Bouwma et al, 2017) whereas directives depend on the necessary uptake at national and regional level (Kettunen et al, 2014). However, regulations from upper-level institutions have been proven to be a possible motivation to adopt the ES concept in practice (Raum, 2018).

\section{Conceptual and Operational Integration}

In order to judge whether the ES concept is represented conceptually in long-term visions or operationally in short-term binding policy, Kettunen et al (2014) suggest distinguishing more precisely between conceptual and operational integration. For Scotland and the EU, policy documents provide a good level of conceptual integration of ES, which is important for general communication and information, notably for NGOs and local officials. Both cases show lacks of operational integration, which is needed to guide decision-makers and administrations (Hatton MacDonald et al, 2014; Bouwma et al, 2017; Claret et al, 2018). This discrepancy is underlined by Rozas-Vasquez et al (2018) and Nordin et al (2017) who detect no ES completely covered over the whole process from conceptual description to concrete policy measures in environmental planning documents in Chile and Sweden. Hence, the holistic development of alternatives to trade off within ES management is inhibited. Only in Ontario (Canada) it is found that the ES concept is explicitly used to motivate and design policy action (Lam and Conway, 2018). 


\begin{tabular}{|c|c|c|c|c|c|c|c|c|c|c|c|c|}
\hline 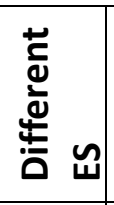 & 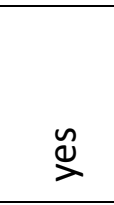 & 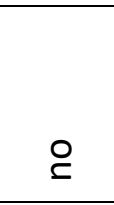 & 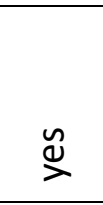 & $\stackrel{\circ}{\complement}$ & 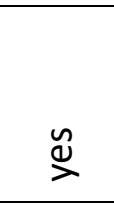 & $\stackrel{\circ}{\complement}$ & 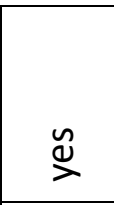 & 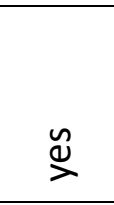 & $\stackrel{\circ}{\complement}$ & $\stackrel{\varrho}{\rightleftharpoons}$ & $\stackrel{\circ}{\complement}$ & 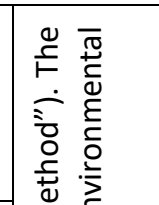 \\
\hline 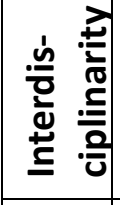 & 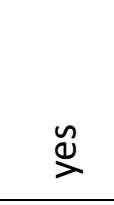 & 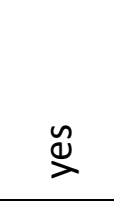 & 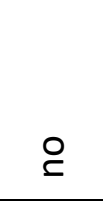 & $\stackrel{\tilde{\nu}}{\rightleftharpoons}$ & $\stackrel{\circ}{\circ}$ & $\stackrel{\tilde{\Perp}}{\supset}$ & $\stackrel{\varrho}{\rightleftharpoons}$ & 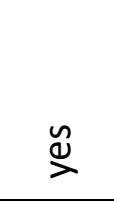 & $\stackrel{\tilde{\nu}}{\rightleftharpoons}$ & 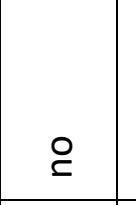 & 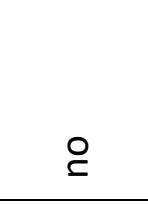 & 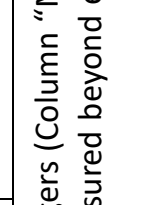 \\
\hline 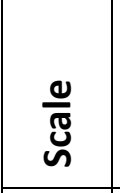 & 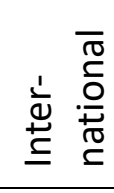 & 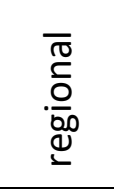 & 厄. & 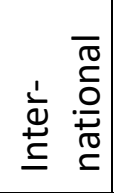 & 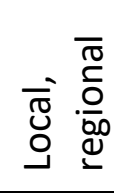 & 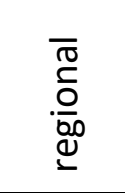 & 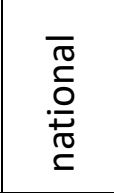 & $\begin{array}{l}\overline{\widetilde{J}} \\
\end{array}$ & 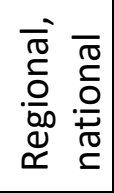 & 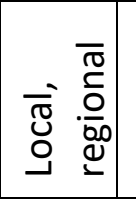 & $\begin{array}{l}\overline{\widetilde{\Xi}} \\
\text { 으 }\end{array}$ & 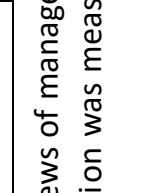 \\
\hline 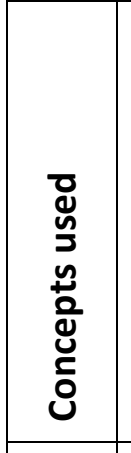 & 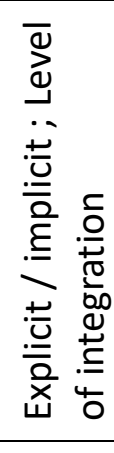 & 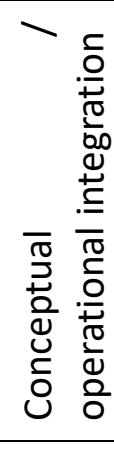 & 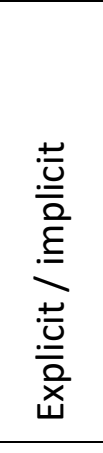 & 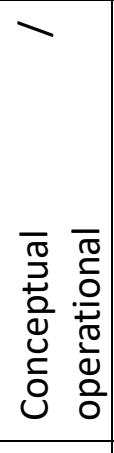 & 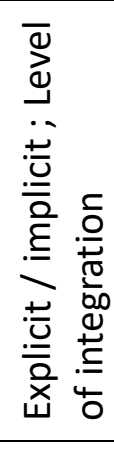 & 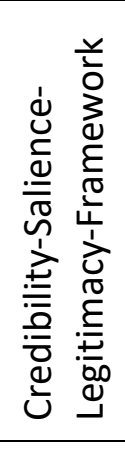 & 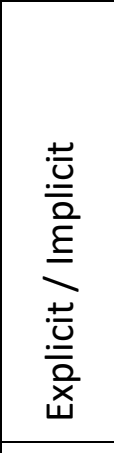 & 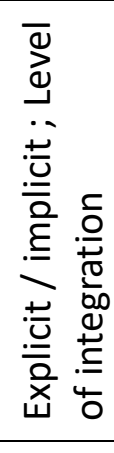 & $\begin{array}{l}0 \\
\tilde{c} \\
z\end{array}$ & 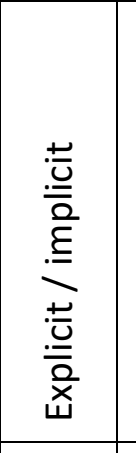 & 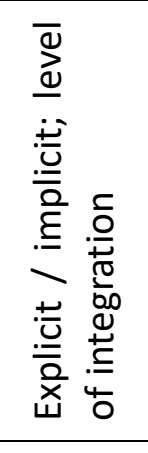 & 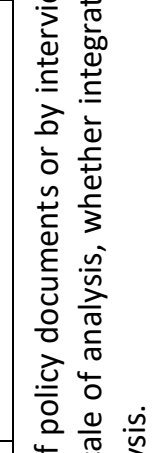 \\
\hline 㜽 & 苂 & 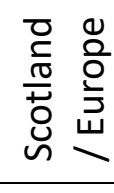 & 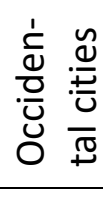 & 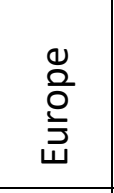 & $\begin{array}{l}\frac{\pi}{0} \\
0 \\
0 \\
0 \\
0\end{array}$ & 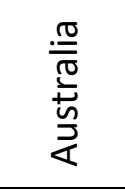 & $\begin{array}{l}\frac{7}{c} \\
\frac{c}{\sigma} \\
0 \\
0\end{array}$ & 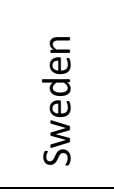 & 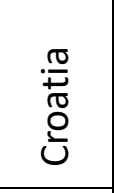 & $\frac{\stackrel{\Perp}{\bar{\tau}}}{\tilde{U}}$ & 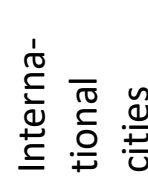 & \\
\hline 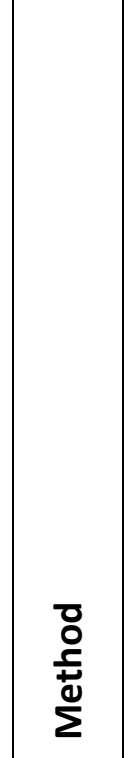 & 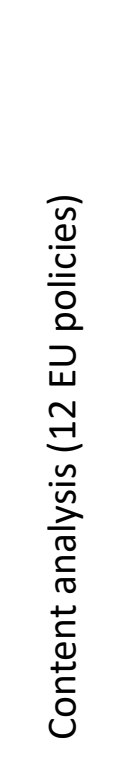 & 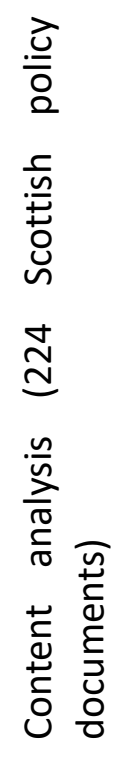 & 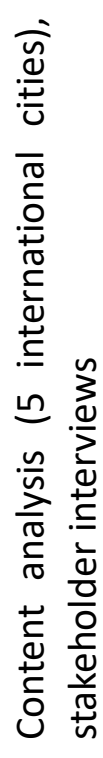 & 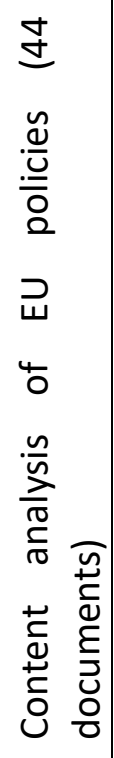 & 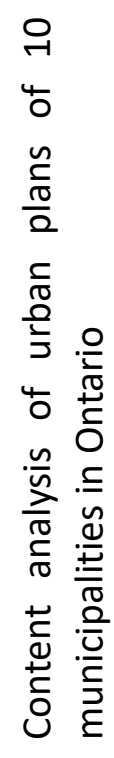 & 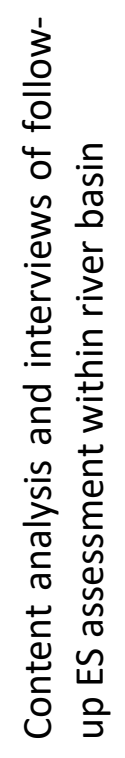 & 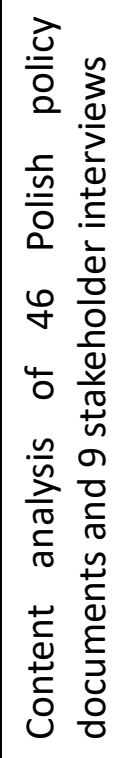 & 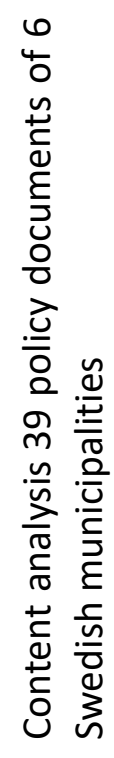 & 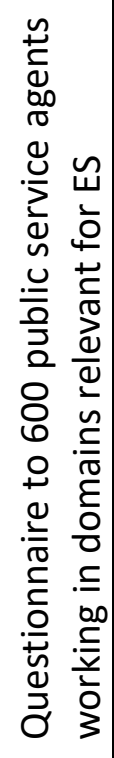 & 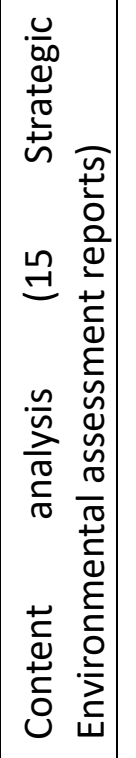 & 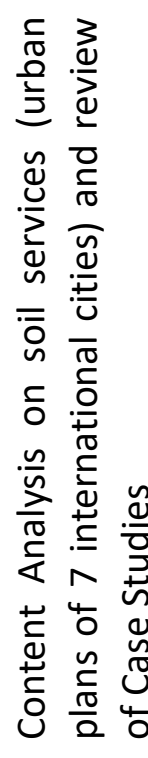 & 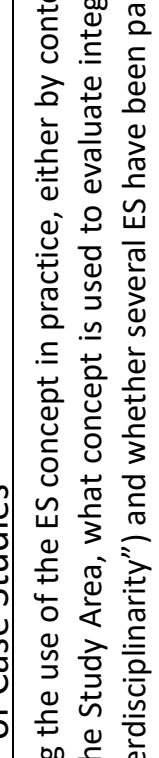 \\
\hline $\begin{array}{l}\frac{n}{0} \\
\frac{5}{3} \\
\frac{3}{\alpha}\end{array}$ & 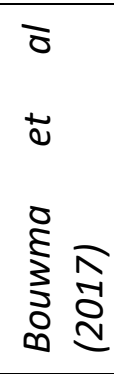 & 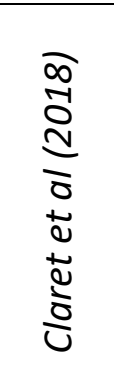 & 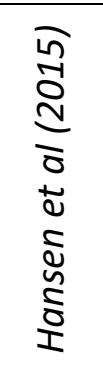 & 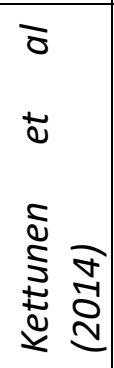 & 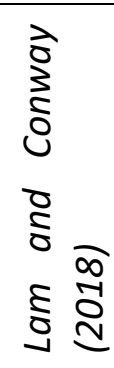 & 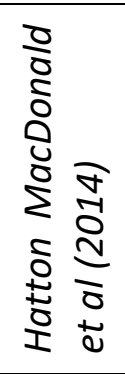 & 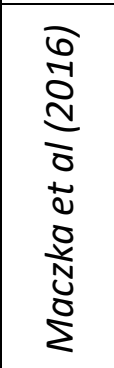 & 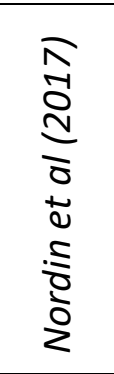 & 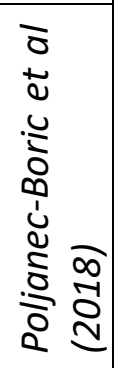 & 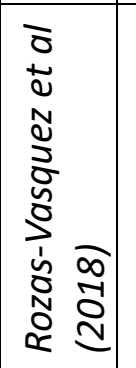 & 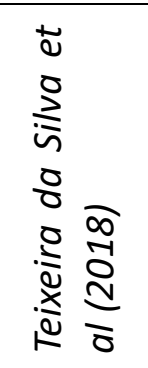 & 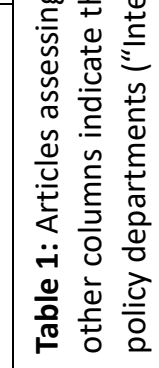 \\
\hline
\end{tabular}




\subsection{Ecosystem Services Concept in the legal system}

The efforts to preserve ES are not only seen as a manner of public decision-making and legislature. Moreover, the enforcement of environmental law is another important step and can help to empower marginalized parts of the population often affected by environmental degradation (Kallis et al, 2013). A general problem is the public good character of ES. Naturally, not having an owner whose rights have been affected, a judgment on their legal distribution, provision or conservation is a source of complications. Furthermore, the intrinsic value attributed to ES cannot be taken into account (Beausonnie, 2018). This change if nature is defined as a legal subject with its own rights, as it is the case in a few countries e.g. in Bolivia, Ecuador, India or New Zealand (Studley and Bleisch, 2018). Several works reviewed and explained the place of the ES concept and valuation techniques within legal enforcement.

First, the implicitness of ES in environmental law is underlined, confirming the analysis for policy documents in section 2.1 (Mauerhofer, 2017). The concept is mostly used in so-called soft law (long-term visions, guidelines) than in enforceable law (Mauerhofer and Laza, 2017). Sharon et al (2018) find 67 cases in common law in English-speaking countries where specific ES are explicitly mentioned, but rather as help to interpret specific cases than as a whole concept. In France, ES are explicitly defined in the National Environmental Law ("Code de l'environnement") since 2004 in order to account for damages on protected natural resources (Doussan, 2018).

Secondly, the use of ES depends on the scale. Given that environmental and urban planning is more often treated by courts at regional or even municipal level, most appearances of the concept are found at this stage rather than in higher-level courts (Sharon et al, 2018). This raises the question whether the complexity and interconnectedness of ES, going beyond administrative borders, can be fully assessed. It is proposed to face this problem by shifting the focus on the habitats and ecosystems, as within the legislation on the Natura 2000 Network (Fevre, 2018). The underlying assumption is that the protection of ES can be achieved by a systemic approach by protecting the environmental "functionality" at the origin of each single ES (Fevre, 2018). At this point, the discussion on the concept of ecological functions (Potschin and Haines-Young, 2016) reemerges.

Thirdly, the economically based interpretation of Ecosystem Services is reflected in most contexts. Several authors report an increasing use of the concepts in combination with questions of valuation (Sharon et al, 2018) or production function based modeling needed for liability litigation 
restoration measures in the US (Adaire and DiPinto, 2018). In the latter case, authors take the case of using choice experiments to judge the adequacy of restoration to offset losses in other habitats. This expands the use of stated preference methods from purely economic applications such as the determination of liability from the Exxon Valdez oil spill (Carson et al, 2003) to other domains. Furthermore, the current focus on economic benefits from ES constitutes a reductionist frame and risks considering less tangible benefits as providing less usefulness for jurisprudence (Doussan, 2018). Here, the inclusion of the expertise of multiple actors such as proposed in most bottom-up implementation frameworks (see section 4) might be helpful.

Although literature provides evidence for influences and needs for the ES concept in jurisdiction, its concrete use is still limited. Mauerhofer and Laza (2017) show in the analysis of expert questionnaires and interviews that the most advanced use of ES in the European Union is within the Invasive Species Act. Meanwhile, the aim of biodiversity is judged to constitute a more important guideline to enforce conservation efforts than associated ES. The use of the ES concept itself will not necessarily change jurisprudence, but can support actual applications and measurement, and motivate additional advocacy from stakeholders, producers and beneficiaries (Doussan, 2018).

\section{Decision-making support by Science-Policy Interfaces}

As stated in the Introduction, science-policy interfaces (SPI) bring together different actors and scientists from different disciplines and administrative levels. By enhancing effective bidirectional transfer of information between knowledge production and decision-making, they are a key element for ES mainstreaming (Sarkki et al, 2014, Young et al, 2014). Before discussing their role in the process of implementation in section 5, we introduce a brief overview of the SPI literature and link it the ES concept. More and more publications present empirical experiences from discussions of peoples involved in these fora (e.g. Hauck et al, 2013; Ruckelshaus et al, 2015; Olander et al, 2017). We will then especially focus on how Economic Valuation can contribute to SPIs by benefit transfer (section 3.2). Meanwhile, a close relationship between valuation conducting researchers and decision-making (through SPIs) can provoke suspicion about the validity of their work (Bishop and Boyle, 2019). This advocacy-credibility trade-off is addressed at the end of this section (see section 3.3). 


\subsection{Challenges and roles of Science-Policy Interfaces}

Most difficulties to include environmental findings in policy-making stem from three kinds of issues (Cash and Moser, 2000). Firstly, an institutional fit problem arises if the management in charge does not operate at the geophysical scale of the environmental issue. Secondly, a scale discordance problem exists when the scale of information assessment is not meeting the informational needs of decision-making. Finally, Cash and Moser (2000) identify cross-scale

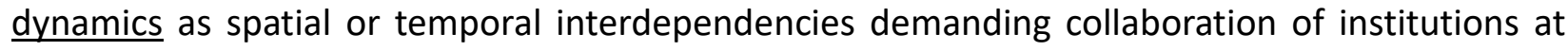
several levels.

In order to address these problems, a unidirectional "pipeline model" is proposed: Information is transferred to the highest possible scale, expecting that the institution in charge is powerful enough to compel institutions at lower scales to tackle the problem appropriately.

A second information transfer model to support a policy goal formation is science-policy interfaces, as defined in the Introduction. In this regard, broader intergovernmental platforms such as the MEA (Millennium Ecosystem Assessment), TEEB or the IPBES (Intergovernmental Science-Policy Platform on Biodiversity and Ecosystem Services) are seen as typical examples of SPIs because they combine different actors from different disciplines and from different administrative levels (Nesshöver et al, 2013, Cash and Moser, 2000).

SPIs can serve as a knowledge broker between science, decision-makers and practitioners to solve cross-disciplinary solutions (Tress et al, 2005, Lang et al, 2012). This is especially useful for boundary objects such as ES, if the limits of existing structures and their current functioning can slow down effective solutions (Thompson Klein, 2004; Mobjörk, 2010).

Another main objective consists of including decision-making into research agendas to enhance relevance and easy use of research outcomes by practitioners (Posner et al, 2016b, Olander et al, 2017, Perez-Soba et al, 2018). Several concrete actions are proposed to strengthen SPIs with most authors emphasizing to focus on processes and projects instead of structures (Nesshöver et al 2013; Sarkki et al, 2014; Young et al, 2014). First, incentives for policy and science have to be created, such as citation measures including gray literature for scientists. This would create appreciation for SPI work in general (Guston, 2001; Sarkki et al, 2014; Young et al, 2014). Secondly, given that decision-making is often relegated from higher-ordered institutions, approaches like compatibility with superior regulations and possible affordance have to be taken into account (Guston, 2001). This would increase relevance for lower-level decision-makers and support faster 
implementation at higher scales, as possible problems are anticipated and accounted for in the research stage. Thirdly, if results are accompanied by the presentation of several policy options, greater scope for negotiation within the policy sector is created (Watson, 2005; Posner et al, 2016b) and decision-makers are forced to demand and apply a more "holistic understanding" in order to discriminate among alternatives. It is argued that these decisions would be more "robust" in the long run (Hirsch and Luzadis, 2013). Others suggest changing publishing mechanisms by more interdisciplinary and inter-domain co-authorship and cross-reviewing between scientists, decision-makers and practitioners (Constanza and Kubiszewski, 2012; Young et al, 2014).

However, the effective inclusion of SPIs needs in research agendas also provoke a "qualityfeasibility trade-off" (Olander et al, 2017) with respect to diverging time horizons between science and decision-making. For example, the demand for quick results by managers limits the use of time-consuming in-depth analyses and participative approaches by researchers (Sarkki et al, 2014). This contradicts recommendations of the SPI literature which underlines the importance of participation, deliberation and stakeholder integration as a way to include local knowledge in the decision-making and implementation process (Spash and Vatn, 2006; Posner et al., 2016b; Lautenbach et al., 2019). Possible long-lasting conflicts harming an effective application could be anticipated and mitigated (Dietz, 2013; Roggero, 2013). This would favor better outcomes in shorter time horizons.

Linked to SPIs, the ES framework serves as an important boundary object that provides a base for collaborative work and creates mutual understanding among working domains and scientific disciplines (Guston, 2001; Young et al, 2014; Steger et al, 2018). Distinctions could be made among different types of ES: whereas provisioning and regulating services are relatively standardized among disciplines, nonmaterial services still deliver a flexible framework for different interpretations and discussions (Reed, 2008; Steger et al, 2018). It is argued that standardization is beneficial for successful interdisciplinary collaboration and effective implementation. In the case of non-material benefits, different notions and understandings still exist. Here, pressure for standardization could overweight the majority point of view and marginalize minority positions (Hirons et al, 2016; Steger et al, 2018).

\subsection{Informational use of Ecosystem Services Valuation: benefit transfer}

The aim to use economic valuations to inform decision-makers and to stress the importance of ES for human well-being is the most common reason to conduct valuation studies and referred to as 
its main purpose (Salles et al, 2011; Chan et al, 2012; Laurans, 2013; Raymond et al, 2014). However, research gaps in combining findings from decision-making theory with ESV are still highlighted (Olander et al, 2017). Therefore, SPIs are mandatory to connect experts in each of these domains and summarize the most important facts for decision-makers and the general public (Young et al, 2014). To support the information transfer among different spatial scales and applications, benefit transfer is seen as a potentially practical and useful approach (Jadhav et al, 2017; Newbold et al, 2018). The problems of transferring benefits arise from the scarcity of data from the initial valuations (Plummer, 2009; Seppelt et al, 2011) but also from the fact that the relationship between the dependent and independent variables may not be the same between the study and policy sites (Richardson et al, 2015). Studies aiming to reproduce or confirm these valuations in order to create a more solid, comparable database as a primary source, are not relevant for publication as they cannot - per se - provide methodological innovations (Eppink et al, 2012; Olander et al, 2017). This also harms the determination of reliance and validity of initial valuations (Bishop and Boyle, 2019). Other caveats are the inclusion of a holistic set of values into benefit transfers (Spash and Vatn, 2006; Atkinson et al, 2012; Chan et al, 2012; Chan et al, 2016) and the ecological comparability of spatially different study areas (Spangenberg and Settele, 2010).

In summary, SPIs are seen as powerful ways to support constructive dialogue and collaboration. Valuations can serve as a way to present economic consequences of several policy options and inform decision-makers. Although several authors mentioned the role of SPI for the implementation stage in general, a methodological classification of implementation contexts is still missing. Implementation research can deliver these theoretical insights.

\subsection{Researchers and advocacy for ES management}

The willingness to mainstream ES in general and to make individual research findings relevant to decision-making in particular, raises the question of how much advocacy for own research interests is necessary or wanted (Laurans and Mermet, 2014). In their key article, Laurans et al (2013) distinguished among three different ways of how ESV is actually used. First, decisionmakers need valuations to trade off different alternatives and finally decide on one of them to be implemented ("decisive"). It retraces how economists aim to deliver relevant cost-benefit analyses. Secondly, in a "technical" setting, valuations are demanded to deliver a specific monetary value which is used for compensations or liabilities (e.g. Adaire and DiPinto, 2018). Finally, "informative" valuations are used to demonstrate value (e.g. Constanza et al, 1997; 
Christie et al, 2012; Gomez-Baggethun and Barton, 2013) and to convince policy-makers to act in favor of the maintenance of ES (Raum, 2018; Su and Peng, 2018). Especially with the last point, researchers are entering a trade-off between credibility and relevance (Sarkki et al, 2014; Posner et al, 2016b), if they focus solely on communicating results they think of being of most concern to the public (Watson, 2005). The risk would be to evolve in a direction of either "politicization of science" or "scientification of politics" (Guston, 2001; Funtowicz and Ravetz, 1994; Lin, 2013). To sustain credibility, researchers are demanded to provide information on their own involvement in NGOs, which could influence the presentation and communication of their findings (Pasgaard et al, 2017). Given the biases introduced by the choice of valuation method (Jacobs et al, 2018) of associated aggregation tools (Martin et Mazzotta, 2018) or the way results of ES studies are presented (Wright et al, 2017), this transparency appears to be important. In fact, further progress by adopting best practice guidelines in the valuation literature (e.g. Johnston et al, 2017) is needed to increase the reliability of results and the validity of approaches (Bishop and Boyle, 2019). Testretest experiments, open access to (meta-) data and a general willingness to publish reproducibility studies without methodological innovations are possible steps to strengthen credibility (Olander et al, 2017, Bishop and Boyle, 2019).

Figure 2 (section 5) illustrates our analysis about how a better implementation process can be achieved. It contains the same elements as figure 1, with the same relations as dotted black arrows. It is turned by 90 degrees so that the key elements of our analysis are in the middle: The consideration of an independent implementation stage leads us to propose a complementary way to enhance decision-making: by especially accounting for caveats in the implementation phase (1), decision-makers might be encouraged to engage in favor of ambitious environmental policy (2). This consideration of implementation needs is supported by SPIs as pointed out in this section. The following section describes what basic approaches have been proposed in implementation research literature and what consequences this could have on the decisions.

\section{Implementation research}

In the previous section, we focused on how the ES concept is mainstreamed in decision-making and how it is supported by SPIs. As discussed in the Introduction, these steps have to be complemented by an analysis of how these public decisions can be implemented by responsible practitioners. This section provides a short overview about Implementation Research and its main theories and findings.

Implementation research is concerned with finding methods that describe and study policy 
implementation (Matland, 1995). The term "implementation" can be defined as the

"Development between the establishment of an apparent intention on the part of government to do something, or to stop doing something, and the ultimate impact in the world of action" (O'Toole, 2000, p.266).

A first review summarizing related literature was provided by Sabatier (1986) and O'Toole (1986). They both divide implementation into two different natures. First, a top-down approach, where a policy goal is defined on a large scale by decision-makers who aim to implement this policy on a more local scale.

Secondly, if a policy goal is arising within in a local context and it is tried to create a network to communicate this goal to higher scales, implementation is realized in a bottom-up context. Both approaches will be analyzed in the following two subsections.

Historically, after initial theoretical reflections in the 1970s, implementation research became popular in the 1980s with several models dealing with the top-down/bottom-up controversy (O'Toole, 2000). Whereas more and more variables influencing policy implementation in one of the two contexts were determined, research focused on the provision of parsimony within the framework (e.g. conflict-ambiguity model in Matland, 1995). Actually, two main research topics can be distinguished (Matland, 1995; O'Toole, 2000): the analysis of policy goals within a topdown or bottom-up approach, and the proposition of a new inclusive framework. We want to contribute to this last point, showing how transdisciplinary work on ESV relates to the traditional framework.

\subsection{Top-down approach}

As described and analyzed by Sabatier (1986), the top-down approach deals with the question whether goals initially defined by policy-makers are achieved and how potential deviation can be explained and limited. Clear policy formulation and a strong bureaucratic sector are seen as important for the successful implementation (Hupe et al, 2014, Povitkina, 2015). A key variable is the so-called "framing" of the policy process. It refers to the power of policy-makers to select implementing organizations, administrations and agencies such as their organizational, legal (section 2.2), human or technological capacities and responsibilities either support or slow down the effective implementation (Matland, 1995). Especially the last point underlines the institutional fit problem identified in the model of information transfer of Cash and Moser (2000): for 
essentially political reasons, controlling or managing establishments may not be capable of covering the responsibility for the entire spatial scale or the methodological complexity of the concerned ES. Consequently, effective environmental policy to conserve or manage ES might be complicated (Chan et al, 2012; Raymond et al, 2014).

The modeling of framing is considered as a major strength of the top-down framework (Sabatier, 1986). Meanwhile, an important concession to bottom-up approaches is the integration of learning processes among project participants within the framework (Rowe and Frewer, 2005). They are seen as facilitators for better integration of ES in decision-making (Cowling et al, 2008).

Sabatier (1986) highlighted several weaknesses of the top-down approach. Firstly, although theoretical progress has been made, top-down models cannot reflect the diversity of possible interactions among agents such as deviations by bureaucrats (e.g. May and Winter, 2007) or possible subsystems and marginalized stakeholders (Roggero, 2013). Secondly, the top-down view represents the position of a central planning institution and devotes more attention to program proponents than to possible opponents, possibly overrating the power of implementing actors in the policy process (Sabatier, 1986). Therefore, top-down approaches appear appropriate for situations where the legislator has strong formal and informal power to pursue framing.

\subsection{The bottom-up approach}

Unlike the top-down approach, the bottom-up method does not depart from an already formulated policy goal, but focuses on strategic interaction among actors to promote a specific aim expressed and pursued at a local level. It is therefore designed to identify a policy network (Sabatier, 1986) and to determine most influential elements within a specific policy domain (socalled "target groups" and "service deliverers") (Matland, 1995).

Rowe and Frewer (2005) provide a detailed review on different participative methods and identify five key factors enhancing successful implementation. First, methods should ensure large participation of relevant actors in the mechanism's sample, i. e. participants coming from the local population affected by or interested in the suggested policy. Hence, the range of impact of the supported goal predetermines the nature of participation. Secondly, facilitators managing the elicitation process need access to complete and relevant information from participants. Accordingly, participants have to be motivated to express themselves actively and to avoid yeasaying (e.g. Reed, 2008). Thirdly, a maximum of information about the project should be provided to increase transparency. This opens up possibilities for participants to deliberate and identify 
"information holes" such as missing data, overly technical language or uncertainties within policy. Fourthly, the participation process should guarantee effective elicitation and transfer of information, for example face-to-face interviews can non-verbal communication such as facial expressions and gestures. Finally, Rowe and Frewer (2005) underline the importance of an effective aggregation technique for communication of results to higher scales. Here the role of the facilitator is critical in ensuring participation from all participants and reporting on the elicitation process in a standardized manner.

The modeling of the interaction of multiple actors is difficult in the top-down framework because of its assumption of vertical command structure, but possible (see previous section). In contrast, it is seen as a major methodological strength of the bottom-up framework, because several structures can exist parallelly and exchange on the same or on higher structural levels ( $O^{\prime}$ Toole, 2000). The legal system (section 2.2) is able to protect and encourage private initiatives or decelerates bottom-up movements (Doyle and Simpson, 2006). Local conditions and knowledge not yet considered by the central planner are accounted for (Matland, 1995) and transaction costs during implementation is reduced (Roggero, 2013).

Meanwhile, indirect effects on participants or on institutional settings (e.g. framing by higher institutions) are difficult to account for within the bottom-up framework (Sabatier, 1986), as some empirical examples in the discussion section will show. This becomes critical for bottom-up approaches as bureaucratic capacity has been found to have more impact in democratic systems than in top-down dominated autocratic ones (Povitkina, 2015).

\subsection{Complementary approaches: Transdisciplinary research within Science-Policy Interfaces}

Bottom-up and top-down modeling give a coherent overview of Implementation Research, but several complementary approaches emerged in the literature such as the influence of bureaucrats (May and Winter, 2007), relations to rhetoric (Hoppe, 2011) or combinations of top-down and bottom-up approaches applied to EU mandatory policy (Newig and Koontz, 2014).

Although not included initially in the framework, the interaction of multiple actors is now an important component of top-down approaches. It is modeled either hierarchically (via representation) or horizontally (via participation) (Hupe et al, 2014). In the first case, higherordered structures are not completely independent from lower institutions. This is achieved by sending representatives from the latter to the former in order to give advice for an efficient implementation design including the needs of lower-ordered institutions. In the second case, 
several decision-makers and implementing practitioners are involved at the same level. Overlapping responsibilities and resulting diverse interests can be modeled and anticipated.

Transdisciplinarity research on ES within SPIs offers great potential to fit into this interaction model. ${ }^{2}$ In the horizontal case, all parties - researchers, decision-makers and practitioners - are collaborating overarchingly. This is, what Mobjörk (2010) calls "Participative Transdisciplinarity" and retraces notions of the bottom-up approach (without being limited to that case). In the hierarchical case, several kinds of actors are represented in the conducting SPI in order to deliver common knowledge of the environmental issue. If this representation is only due to legal obligation instead of "organizational culture" (Reed, 2008), collaboration of one party risks to be constrained to the position of giving advice. "Consultative Transdisciplinarity" is the term used by Mobjörk (2010) for this scenario. Meanwhile, close collaboration among parts of parties in SPIs can cause problems of legitimacy: scientific experts and bureaucrats in charged implementation are able to produce efficient, rational solutions but not as the legitimate result of a vote (Hupe, 2014).

In summary, top-down approaches are appropriate in situations where the legislator has strong formal and informal power to pursue framing. Bottom-up approaches are seen as adequate for situations with an interest in local dynamics or with the influence of many actors and without hierarchical power relations. Implementation Research is complemented by intermediate models and case analyses (Saetren, 2005). In the following discussion section, we describe how valuation approaches for ES and transdisciplinary research fits well with these implementation contexts.

We refer here to figure 2: the implementation bubble can be divided into a bottom-up case and a top-down case, having each different needs. Nevertheless, this division is not sharp as illustrated by the dashed line. In order to transfer these needs to researchers and decision-makers, SPIs have to integrate practitioners within a transdisciplinary setting (illustrated by the red arrows). Consultative transdisciplinarity corresponds mainly to the top-down approach, whereas participative transdisciplinarity corresponds to the bottom-up approach. It is noteworthy that SPIS are therefore able to enhance the decision-making and implementation process in both implementation contexts.

\footnotetext{
${ }^{2}$ We thank one of the reviewers for the idea to develop the discussion of transdisciplinarity in the context of implementation research.
} 


\section{Policy implementation and Valuation methods: Empirical evidence}

As pointed out in the introduction, there are numerous discussions about the limitations and advantages of deliberative and traditional monetary valuation techniques in the literature. Meanwhile, Laurans et al (2013) showed that limited focus has been put on whether valuations have been used for decision-making at all. In this section, we want to widen the discussion about appropriate valuation methods to the question of how they correspond to the needs and key variables of different implementation approaches. Beginning with the bottom-up approach, we will assess whether deliberative and traditional monetary valuations meet criteria for successful implementation. We will show that implementation context has diverging impacts on the effectiveness of information transfers from different valuation approaches. Meanwhile, adaptation of the valuation to the needs of SPIs regardless of implementation contexts seems to be an even more important issue.

\subsection{The bottom-up case}

For every key factor identified by Rowe and Frewer (2005), we analyze whether empirical deliberative studies facilitate the implementation and dedicate how traditional monetary techniques would perform.

First, regarding the maximization of relevant participants, two main techniques in deliberative approaches can be distinguished. The first one is the use of focus groups to improve valuation surveys, which is widely recommended (Chilton and Hutchinson, 1999, Johnston et al, 2017). The second method is citizen juries where stakeholders get directly involved in the valuation process or invited to give share their view (e.g. Hattam, 2015, Reed, 2008). Hence, the question is not primarily about the choice of the valuation method but rather about the design and preparation of the final empirical study. Indeed, Rowe and Frewer (2005) stress that not only representation of main ideas is important for bottom-up success, but that a high proportion of affected and interested population should be actively involved in the process. Given that deliberation entails higher administrative and organizational costs for a given intended sample (Rauschmayer and Wittmer, 2006), traditional monetary techniques can help to reach a larger sample, especially in the context of budgetary constraints (Jadhav et al, 2017). Hence, it provides advantages if local policy aims are affecting a high number of individuals and demands elaboration of a large sample, which would also contribute to a better modeling of the reliability of results (Bishop and Boyle, 2019). 
Secondly, for the maximization of the amount of relevant information, several indicators are used: (i) an increasing mental connection to the environmental good raised in group discussions (Völker and Lienhoop, 2016); (ii) lower protest response rates and motivation to active participation in deliberative settings (Philip and Macmillan, 2005; Szabo, 2011) or (iii) higher satisfaction with the process of discussion, the outcomes or motivation to get voluntarily involved in the topic (Gregory and Wellman, 2001; Szabo, 2011). Meanwhile, discussion in deliberative approaches can also lead to the monopolization or the domination of certain views (e.g. Dietz et al, 2009; Hattam et al, 2015) and exclusion of minority positions in the process (e.g. Ito et al, 2009). Again, attention has to be paid to design issues in deliberative valuation, such as the moderator effect (Lienhoop and Völker, 2016). A widely discussed problem of traditional monetary is value monism. The focus on the provision of monetary values could marginalize incommensurate and intrinsic values (GomezBaggethun and Martin-Lopez, 2015). Consequently, parts of plural value dimensions and local knowledge (especially about nonmaterial ES) are not adequately assessed and used.

Thirdly, the quantity of relevant information given from organizers to respondents can be modulated in deliberative approaches. Possible solutions are to give participants more time to think (Macmillan et al, 2002) or to mobilize expert opinion such as in citizen juries. This contributes to trust-building (Hattam et al, 2015), which is especially important for possible applications in SPIs. This flexibility corresponds to a varying perception of the "optimal" information quantity among participants in valuation studies (Lienhoop and Macmillan, 2007). It contrasts traditional valuation, in which given information is mostly predetermined by the researchers.

The fourth point mentioned by Rowe and Frewer (2005) concerns the inclusion of non-verbal communication. As before, this is a question of the practical design of valuation studies independent from methodological issues.

Finally, effective aggregation is important to combine findings from individuals (Rowe and Frewer, 2005). Deliberative techniques suffer from small sample sizes and therefore less representativeness than more easily conductible traditional monetary techniques (Bunse et al, 2015). Focusing on political instead of statistical representativeness can mitigate this problem (Lienhoop and Völler, 2016), but it is unclear whether this suffices to serve as a base for aggregation. As mentioned above, aggregation undermines the incorporation of fairness and plural values (Spash, 2007; Spangenberg and Settele, 2010). Aggregation methods for nonmonetary values exist, especially for multi-criteria assessments, but have an impact on the ordinal 
scale of possible management alternatives (Martin and Mazzotta, 2018). Meanwhile, monetary techniques facilitate aggregation but it is questionable whether "all relevant information" is included (Rowe and Frewer, 2005, p. 273). Especially in the case of incommensurate data, deliberative techniques appear preferable, especially if the results do not have to be aggregated afterwards. If the analysis of local phenomena treated by a bottom-up approach implies further aggregation of outcomes, monetary techniques provide advantages in aggregation and representativeness due to higher possible sample sizes. Further investigation is needed on how information not included by this technique can be integrated in qualitative measurements and aggregated to higher scales, depending on decision-makers' preferences (Martin and Mazotta, 2018).

\subsection{The top-down case}

The literature on top-down implementations of environmental projects assessment is less abundant than for bottom-up approaches. Whereas the key variables suggested by Sabatier (1986) and Hupe et al (2014) are focused on different ways of framing from the central planner, empirical evidence from environmental studies involving top-down implementation is scarce. As we do not feel able to classify all the policy contexts of studies as bottom-up or top-down, we present studies which explicitly mentioned being in a "top-down" setting, whose importance is highlighted by the debate on Eco-Authoritarianism (e.g. Gilley, 2012; Shahar, 2015).

Liu et al (2008) present environmental projects that improved forest cover and reduce soil erosion in China. They find positive effects on poverty alleviation due to higher diversification of activities and income sources. This could be strengthened by strategic planning concepts which include the needs of impacted individuals and stakeholders (Liu et al, 2008). Nevertheless, less participative, traditional monetary valuation is the most widely used method for ESV in China (Jiang, 2017). Likewise, in Kyrgyzstan, Carter et al (2003) report the introduction of corporate forest management within a top-down and centralized decision-making tradition. They mention a lack of culture of questioning orders and missing experience with local collaborations.

A comparison between the outcomes of bottom-up and top-down driven projects in Vietnam is elaborated by Castella et al (2007). Trust of stakeholders in methodologies is identified as a key element for successful implementation. To achieve this goal, they suggest establishing mediation platforms charged with (i) identification of cross-scale dynamics and (ii) interaction and coordination among stakeholders. SPI would therefore be an effective tool to combine top-down 
and bottom-up strengths in this context.

Indeed, SPIs may fail if power structures are centralized (contrary to strong regional authorities in Vietnam, Castella et al, 2007) or can easily be redistributed among different authorities. These risks have been revealed by two studies on a conservation program in Egypt (Sowers, 2007) and green policy implementation in Burma and Iran (Doyle and Simpson, 2006). The former describes how local Bedouin communities were successfully integrated into the elaboration of a local national park conservation program in South Sinai by the park's administration. After the transfer of responsibility to an agency in charge of tourism development, restrictions for the tourism sector were softened and local population was omitted, resulting in the loss of the conservation success achieved before. In Doyle and Simpson (2006), local environmental groups in Burma are strictly controlled by the central state and in Iran, green NGOs were seen as a possibility to support the expression of groups marginalized in society such as young women. Meanwhile, by providing insufficient financial support, the central government ensured that it was not challenged by these organizations.

These examples show that the possibility to create structures comparable to SPI in top-down approaches is not sufficient to create facilities to encourage implementation or information transfer. Furthermore, they have to be fully integrated and not marginalized in the policy process (Stringer, 2007), making them dependent on existing political power structures. As it has been shown in the example from Egypt, extensive efforts have to be made in order to get a holistic set of values, providing valuable information for decision-makers. But this additional effort might be fruitless if institutional structures and responsibilities in the political process are changed, as it is often the case in top-down contexts.

A promising approach to mitigate these issues is to link top-down and bottom-up characteristics in order to exploit complementarities (e.g. Fraser, 2006; Newig and Koontz, 2014). Within a topdown context, participative methods have successfully been applied and revealed local preferences and knowledge in the establishment of national park management policies (Zhang et al, 2013). Meanwhile, willingness to use these methods is dependent on governmental support and implementation framing (Stringer, 2007; Zhang et al, 2013).

\subsection{Complementarity of the valuation approaches for transdisciplinary implementation by Science-Policy Interfaces}

The analysis of the bottom-up case revealed complementarities between monetary and 
deliberative valuation methods. In cases where local knowledge and perception are important, the analysis benefits from deliberation. If the goods or services valued exceed the local context and if aggregation is demanded, monetary assessment should accompany deliberations.

In the top-down contexts, many studies reported the willingness to establish and institutionalize classical bottom-up structures such as SPI in order to transform and adapt initially formulated policy goals at higher scales to local conditions and needs (e.g. Doyle and Simpson, 2006; Newig and Koontz, 2014). These organizations act as multidirectional mediators in the implementation process, capable of enhancing public policies in top-down contexts, if the institutional setting allows (Castella, 2007).

Consequently, valuations should integrate the needs of SPIs if they are aimed to be used in practice. On the one hand, this means that deliberative elements are useful for meeting the integrative needs of transdisciplinary research. On the other hand, as power structures can change rapidly in top-down contexts (Sowers, 2007), and if effective aggregation is important, standard monetary techniques appear important in order to ensure that structured, complementary information can be transferred easily.

This is retraced in figure 2: the two kinds of valuation are complementary in the way they address key issues of implementation: whereas deliberative approaches are able to furnish the integrative elements needed in bottom-up approaches, traditional monetary valuation might be helpful in top-down contexts, when fast and aggregated measures are needed. As Bartkowski and Lienhoop (2017) as well as Kenter et al (2019) note, deliberative monetary valuation is a way to combine both. 


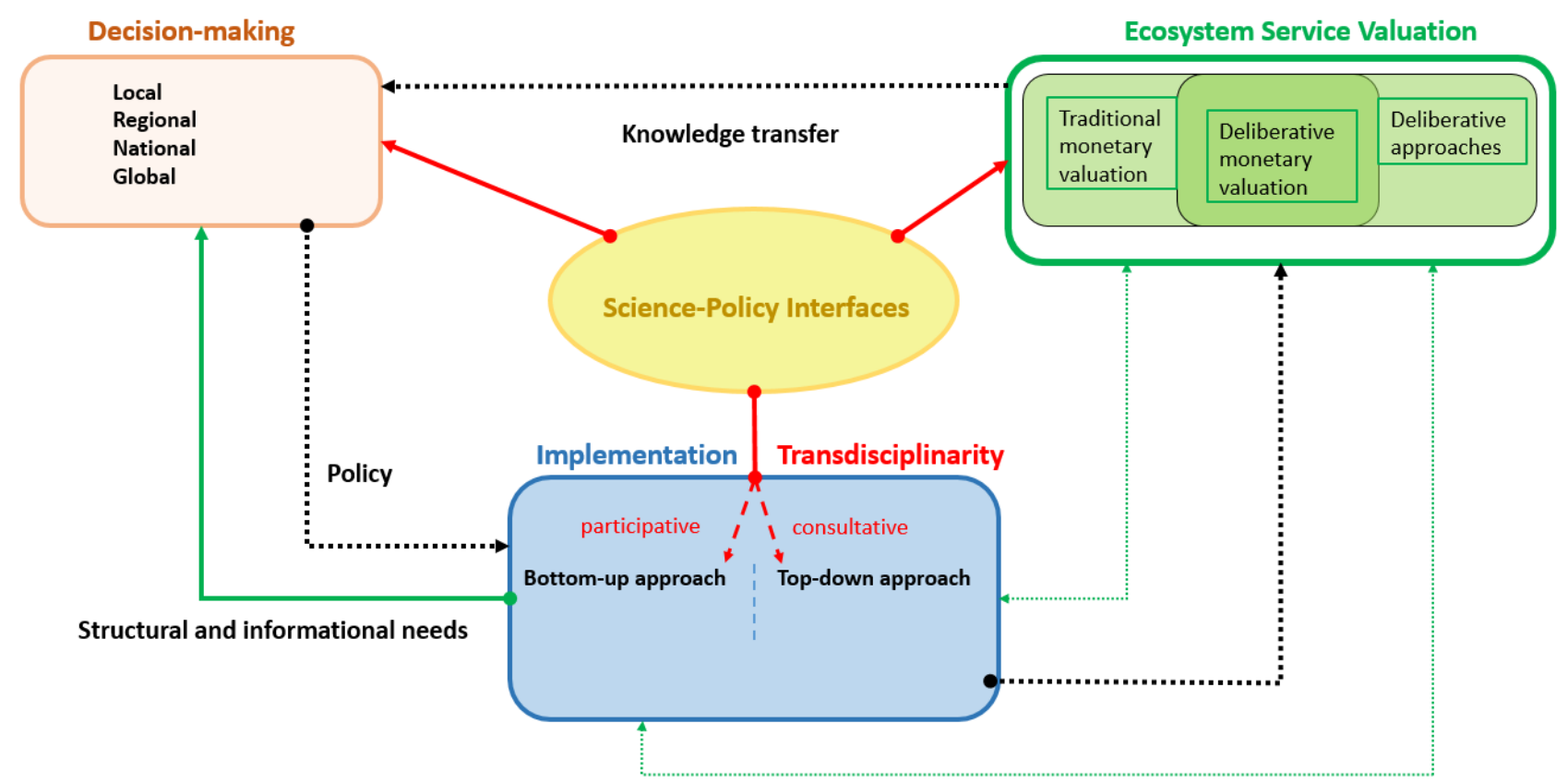

Figure 2: Complementary vision of the implementation process

The initial classical process is presented by the dashed black arrows and complemented by our drawbacks from implementation research and transdisciplinary research.

\section{Conclusion}

After the identification of research needs to close the implementation gap (Laurans et al, 2013; Levrel et al, 2017), a growing literature reports on empirical experiences from collaborations with decision-makers (Ruckelshaus et al, 2015; Olander et al, 2017), or provides content analyses on strategic policy and planning documents (e.g. Hansen et al, 2015; Noe et al, 2017; Rozas-Vasquez et al, 2018). Hence, further research is expected to contribute to the identification of opportunities to enhance dialogue and collaboration among scientists, decision-makers and practitioners, notably through science-policy interfaces (Häyhä et al, 2016).

For instance, the impacts of implementation contexts are still not well elaborated, although it provides a more detailed insight into decision-makers' and practitioners' needs. This contributes to this transdisciplinary research agenda in three ways. First, we have to highlight the interest of broadening the debate from the sole question of how ecosystem service valuation (ESV) can inform decision-making to a more integrative approach of how ESV can improve decision-making and its implementation. Our aim has been to widen this stage by incorporating the needs for implementation into assessment and valuation, in particular by using different complementary valuation techniques. This may result in greater efficiency when potential problems and conflicts have been anticipated and accounted for in earlier stages. 
Secondly, we highlighted the potential role that science-policy interfaces (SPIs) can play in different implementation contexts: we found complementarities in their ability to meet implementation needs in top-down and bottom-up contexts. The structural needs of SPIs correspond to the aim of transmitting information from science into politics and from local evidence to global action and vice versa.

Thirdly, we applied our analysis to different techniques for the economic valuation of ecosystem services. Deliberative approaches have shown to provide the integrative elements needed for science-policy interfaces, in particular by revealing a more holistic set of values than traditional monetary valuation. This is especially useful in bottom-up contexts. Nevertheless, creating tools to facilitate aggregation is a major challenge for future research (Murphy et al, 2017; Martin and Mazotta, 2018). In top-down contexts, if existing power structures are such that the policy-making process is framed by a central authority or mainly driven by experts, valuation might be limited to solely inform about or demonstrate value. This could be adequately furnished by monetary valuation. SPIs are able to support the implementation process in either context.

For ESV, the use of different methods not only gives opportunities for integrating different user groups and value types (Jacobs et al, 2018), but also for exploiting complementarities between top-down and bottom-up contexts. If researchers focus on improving the relevance of their results to policy makers and practitioners, these complementarities should be used such as to enhance the transdisciplinary scope of SPI.

\section{Acknowledgements}

We thank Yann Laurans and Samson Zadmehran for valuable comments on earlier drafts of this work. We also thank numerous members from the CEE-M and Joaquin Ameller Pavez, Driss Ezzine de Blas, and Philippe Méral for suggested literature. We finally thank two anonymous reviewers for their comments that considerably improved the paper.

\section{Funding Sources}

This research did not receive any specific grant from funding agencies in the public, commercial, or not-for-profit sectors. 


\section{References}

Adaire, C., Dipinto, L., 2018. The role of ecosystem services in USA natural resource liability litigation. Ecosyst. Serv. 29, 333-351. https://doi.org/10.1016/j.ecoser.2017.03.015

Atkinson, G., Bateman, I.J., Mourato, S., 2012. Recent advances in the valuation of ecosystem services and biodiversity. Oxford Rev. Econ. Policy 28, 22-47. https://doi.org/10.1093/oxrep/grs007

Bartkowski, B., Lienhoop, N., 2017. Democracy and valuation: A reply to Schläpfer (2016). Ecol. Econ. 131, 557-560. https://doi.org/10.1016/j.ecolecon.2016.05.011

Beaussonie, G., 2018. The legal definition of ecosystem services, in: Ecosystem Services and Soil Protection - Legal Analyses and Agronomic Insights. pp. 76-86.

Bishop, R.C., Boyle, K.J., 2019. Reliability and Validity in Nonmarket Valuation. Environ. Resour. Econ. 72, 559-582. https://doi.org/10.1007/s10640-017-0215-7

Bouwma, I., Schleyer, C., Primmer, E., Winkler, K.J., Berry, P., Young, J., Carmen, E., Špulerová, J., Bezák, P., Preda, E., Vadineanu, A., 2017. Adoption of the ecosystem services concept in EU policies. Ecosyst. Serv. https://doi.org/10.1016/j.ecoser.2017.02.014

Bunse, L., Rendon, O., Luque, S., 2015. What can deliberative approaches bring to the monetary valuation of ecosystem services? A literature review. Ecosyst. Serv. 14, 88-97.

Carson, R.T., Mitchell, R.C., Hanemann, M., Kopp, R.J., Presser, S., Ruud, P.A., 2003. Contingent valuation and lost passive use: Damages from the Exxon Valdez oil spill. Environ. Resour. Econ. 25, 257-286.

Carter, J., Steenhof, B., Haldimann, E., Nurlan, A., 2003. Collaborative Forest Management in Kyrgyzstan:Moving From Top-Down to Bottom-Up Decision-Making. Gatekeeper Ser. No. 108 Int. Inst. Environ. Dev.

Cash, D.W., Moser, S.C., 2000. Linking global and local scales: dynamic assessment and management processes. Glob. Environ. Chang. 10, 109-120. https://doi.org/10.1016/S0959-3780(00)00017-0

Castella, J.C., Pheng Kam, S., Dinh Quang, D., Verburg, P.H., Thai Hoanh, C., 2007. Combining top-down and bottom-up modelling approaches of land use/cover change to support public policies: Application to sustainable management of natural resources in northern Vietnam. Land use policy 24, 531-545. https://doi.org/10.1016/i.landusepol.2005.09.009

Chan, K.M.A., Guerry, A.D., Balvanera, P., Klain, S., Satterfield, T., Basurto, X., Bostrom, A., Chuenpagdee, R., Gould, R., Halpern, B.S., Levine, J., Norton, B., Ruckelshaus, M., Russell, R., Tam, J., 2012. Where are Cultural and Social in Ecosystem Services? A Framework for Constructive Engagement. Bioscience 62, 744-756.

https://doi.org/10.1525/bio.2012.62.8.7 
Chan, K.M.A., Anderson, E., Chapman, M., Jespersen, K., Olmsted, P., 2016. Payments for Ecosystem Services: Rife with Problems and Potential - for Transformation towards Sustainability. Ecol. Econ. 140, 1-24. https://doi.org/10.1016/j.ecolecon.2017.04.029

Cheng, X., Van Damme, S., Li, L., Uyttenhove, P., 2019. Evaluation of cultural ecosystem services: A review of methods. Ecosyst. Serv. 37, 100925. https://doi.org/10.1016/j.ecoser.2019.100925

Chilton, S.M., Hutchinson, W.G., 1999. Do focus groups contribute anything to the contingent valuation process? J. Econ. Psychol. 20, 465-489.

Christie, M., 2012. Approaches to valuing ecoystem services in developing countries, in: Mainstreaming Ecosystem Services Approaches into Development: Application of Economic Valuation for Designing Innovative Response Policies. pp. 1-66.

Claret, C., Metzger, M.J., Kettunen, M., ten Brink, P., 2018. Understanding the integration of ecosystem services and natural capital in Scottish policy. Environ. Sci. Policy 88, 32-38. https://doi.org/10.1016/j.envsci.2018.05.019

Constanza, R., D'Arge, R., de Groot, R.S., Farber, S., Grasso, M., Hannon, B., Limburg, K., Naeem, S., O’Neill, R. V., Paruelo, J., Raskin, R.G., Sutton, P., van den Belt, M., 1997. The value of the world's ecosystem services and natural capital. Nature 387, 253-260.

Constanza, R., Kubiszewski, I., 2012. The authorship structure of "ecosystem services" as a transdisciplinary field of scholarship. Ecosyst. Serv. 1, 16-25.

https://doi.org/10.1016/j.ecoser.2012.06.002

Cowling, R.M., Egoh, B., Knight, A.T., O’Farrell, P.J., Reyers, B., Rouget, M., Roux, D.J., Welz, A., Wilhelm-Rechman, A., 2008. An operational model for mainstreaming ecosystem services for implementation. Proc. Natl. Acad. Sci. U. S. A. 105, 9483-9488.

https://doi.org/10.1073/pnas.0706559105

Daily, G.C., Polasky, S., Goldstein, J., Kareiva, P.M., Mooney, H.A., Pejchar, L., Ricketts, T.H., Salzman, J., Shallenberger, R., 2009. Ecosystem services in decision-making: Time to deliver. Front. Ecol. Environ. 7, 21-28. https://doi.org/10.1890/080025

de Groot, R.S., Brander, L., van der Ploeg, S., Costanza, R., Bernard, F., Braat, L., Christie, M., Crossman, N.D., Ghermandi, A., Hein, L., Hussain, S., Kumar, P., McVittie, A., Portela, R., Rodriguez, L.C., ten Brink, P., van Beukering, P., 2012. Global estimates of the value of ecosystems and their services in monetary units. Ecosyst. Serv. 1, 50-61.

https://doi.org/10.1016/j.ecoser.2012.07.005

Dietz, T., Stern, P.C., Dan, A., 2009. How Deliberation Affects Stated Willingness to Pay for Mitigation of Carbon Dioxide Emissions: An Experiment. Land Econ. 85, 329-347. https://doi.org/10.1353/lde.2009.0019 
Dietz, T., 2013. Bringing values and deliberation to science communication. Proc. Natl. Acad. Sci. U. S. A. 110 Suppl, 14081-7. https://doi.org/10.1073/pnas.1212740110

Doussan, I., 2018. A brief history of the incorporation of the concept of ecosystem services in law, in: Ecosystem Services and Soil Protection - Legal Analyses and Agronomic Insights. pp. 53-59.

Doyle, T., Simpson, A., 2006. Traversing more than speed bumps: Green politics under authoritarian regimes in Burma and Iran. Env. Polit. 15, 750-767. https://doi.org/10.1080/09644010600937199

Eppink, F. V., Werntze, A., Mäs, S., Popp, A., Seppelt, R., 2012. Land Management and Ecosystem Services. Gaia Ecol. Perspect. Sci. Soc. 1, 55-63.

European Commission, 2013. System of Accounting 2012 - Experimental Ecosystem Accounting.

Falk, T., Spangenberg, J.H., Siegmund-schultze, M., Kobbe, S., Kuebler, D., Settele, J., Vorlaufer, T., Dufhues, T., 2018. Identifying governance challenges in ecosystem services management. Ecosyst. Serv. 32, 193-203.

Fèvre, M., 2018. "Ecosystem services", a functional concept, in: Ecosystem Services and Soil Protection - Legal Analyses and Agronomic Insights. pp. 60-75.

Fisher, B., Turner, R.K., Morling, P., 2009. Defining and classifying ecosystem services for decision-making. Ecol. Econ. 68, 643-653. https://doi.org/10.1016/j.ecolecon.2008.09.014

Fraser, E.D.G., Dougill, A.J., Mabee, W.E., Reed, M., McAlpine, P., 2006. Bottom up and top down: Analysis of participatory processes for sustainability indicator identification as a pathway to community empowerment and sustainable environmental management. J. Environ. Manage. 78, 114-127. https://doi.org/10.1016/j.jenvman.2005.04.009

Funtowicz, S., Ravetz, J.R., 1994. The worth of a songbird: ecological economics as a post-normal science. Ecol. Econ. 8009, 197-207. https://doi.org/10.1016/0921-8009(94)90108-2

Gilley, B., 2012. Authoritarian environmentalism and China's response to climate change. Env. Polit. 21, 287-307. https://doi.org/10.1080/09644016.2012.651904

Gómez-Baggethun, E., Barton, D.N., 2013. Classifying and valuing ecosystem services for urban planning. Ecol. Econ. 86, 235-245. https://doi.org/10.1016/j.ecolecon.2012.08.019

Gómez-Baggethun, E., Martín-López, B., 2015. Ecological economics perspectives on ecosystem services valuation. Handb. Ecol. Econ. 260-282. https://doi.org/10.4337/9781783471416

Gregory, R., Wellman, K., 2001. Bringing stakeholder values into environmental policy choices: a community-based estuary case study. Ecol. Econ. 39, 37-52.

Guerry, A.D., Polasky, S., Lubchenco, J., Chaplin-Kramer, R., Daily, G.C., Griffin, R., Ruckelshaus, M., Bateman, I.J., Duraiappah, A., Elmqvist, T., Feldman, M.W., Folke, C., Hoekstra, J., Kareiva, P.M., Keeler, B.L., Li, S., McKenzie, E., Ouyang, Z., Reyers, B., Ricketts, T.H., 
Rockström, J., Tallis, H., Vira, B., 2015. Natural capital and ecosystem services informing decisions: From promise to practice. Proc. Natl. Acad. Sci. 112, 7348-7355.

https://doi.org/10.1073/pnas.1503751112

Guston, D.H., 2001. Boundary Organizations in Environmental Policy and Science: An Introduction. Sci. Technol. Human Values 26, 399-408.

https://doi.org/10.1177/016224390102600401

Hansen, R., Frantzeskaki, N., McPhearson, T., Rall, E., Kabisch, N., Kaczorowska, A., Kain, J.H., Artmann, M., Pauleit, S., 2015. The uptake of the ecosystem services concept in planning discourses of European and American cities. Ecosyst. Serv. 12, 228-246.

https://doi.org/10.1016/j.ecoser.2014.11.013

Hattam, C., Böhnke-Henrichs, A., Börger, T., Burdon, D., Hadjimichael, M., Delaney, A., Atkins, J.P., Garrard, S., Austen, M.C., 2015. Integrating methods for ecosystem service assessment and valuation: Mixed methods or mixed messages? Ecol. Econ. 120, 126-138. https://doi.org/10.1016/j.ecolecon.2015.10.011

Hatton MacDonald, D., Bark, R.H., Coggan, A., 2014. Is ecosystem service research used by decision-makers? A case study of the Murray-Darling Basin, Australia. Landsc. Ecol. 29, 1447-1460. https://doi.org/10.1007/s10980-014-0021-3

Hauck, J., Go, C., Varjopuro, R., Ratama, O., Jax, K., 2013. Benefits and limitations of the ecosystem services concept in environmental policy and decision-making: Some stakeholder perspectives. Environ. Sci. Policy 25, 13-21. https://doi.org/10.1016/j.envsci.2012.08.001

Häyhä, T., Lucas, P.L., van Vuuren, D.P., Cornell, S.E., Hoff, H., 2016. From Planetary Boundaries to national fair shares of the global safe operating space - How can the scales be bridged? Glob. Environ. Chang. 40, 60-72. https://doi.org/10.1016/j.gloenvcha.2016.06.008

Hirons, M., Comberti, C., Dunford, R., 2016. Valuing Cultural Ecosystem Services. Annu. Rev. Environ. Resour. 41, 545-574. https://doi.org/10.1146/annurev-environ-110615-085831

Hirsch, P.D., Luzadis, V.A., 2013. Scientific Concepts and Their Policy Affordances: How a Focus on Compatibility Can Improve Science-Policy Interaction and Outcomes. Nat. Cult. 8, 97118. https://doi.org/10.3167/nc.2013.080106

Hoppe, R., 2011. Institutional constraints and practical problems in deliberative and participatory policy making. Policy Polit. 39, 163-186. https://doi.org/10.1332/030557310X519650

Hupe, P., 2014. What Happens on the Ground: Persistent Issues in Implementation Research. Public Policy Adm. 29, 164-182.

Hupe, P., Nangia, M., Hill, M., 2014. Studying Implementation Beyond Deficit Analysis: Reconsidering the Top-Down View. Public Policy Adm. 29, 145-163. 
Ito, N., Takeuchi, K., Kuriyama, K., Shoji, Y., Tsuge, T., Mitani, Y., 2009. The influence of decisionmaking rules on individual preference for ecological restoration: Evidence from an experimental survey. Ecol. Econ. 68, 2426-2431.

Jacobs, S., Martín-lópez, B., Barton, D.N., Dunford, R., Harrison, P.A., Kelemen, E., Saarikoski, H., Termansen, M., García-Ilorente, M., Gómez-Baggethun, E., Kopperoinen, L., Luque, S., Palomo, I., Priess, J.A., Rusch, G.M., Tenerelli, P., Turkelboom, F., Demeyer, R., Hauck, J., Keune, H., Smith, R., 2018. The means determine the end - Pursuing integrated valuation in practice. Ecosyst. Serv. 29, 515-528. https://doi.org/10.1016/j.ecoser.2017.07.011

Jadhav, A., Anderson, S., Dyer, M.J.B., Sutton, P.C., 2017. Revisiting Ecosystem Services: Assessment and Valuation as Starting Points for Environmental Politics. Sustainability 9, 1755. https://doi.org/10.3390/su9101755

Jiang, W., 2017. Ecosystem services research in China: A critical review. Ecosyst. Serv. 26, 10-16. https://doi.org/10.1016/j.ecoser.2017.05.012

Johnston, R.J., Russell, M., 2011. An operational structure for clarity in ecosystem service values. Ecol. Econ. 70, 2243-2249. https://doi.org/10.1016/j.ecolecon.2011.07.003

Johnston, R.J., Boyle, K.J., Adamowicz, W.L., Bennett, J., Brouwer, R., Cameron, T.A., Hanemann, M.W., Hanley, N., Ryan, M., Scarpa, R., Tourangeau, R., Vossler, C.A., 2017. Contempory Guidance for Stated Preference Studies. J. Assoc. Environ. Resour. Econ. 4, 319-405.

Kallis, G., Gómez-Baggethun, E., Zografos, C., 2013. To value or not to value? That is not the question. Ecol. Econ. 94, 97-105. https://doi.org/10.1016/j.ecolecon.2013.07.002

Kettunen, M., ten Brink, P., Underwood, E., Salomaa, A., 2014. Policy needs and opportunities for operationalising the concept of ecosystem services.

Lam, S.T., Conway, T.M., 2018. Ecosystem services in urban land use planning policies: A case study of Ontario municipalities. Land use policy 77, 641-651.

https://doi.org/10.1016/j.landusepol.2018.06.020

Lang, D.J., Wiek, A., Bergmann, M., Stauffacher, M., Martens, P., Moll, P., Swilling, M., Thomas, C.J., 2012. Transdisciplinary research in sustainability science: Practice, principles, and challenges. Sustain. Sci. 7, 25-43. https://doi.org/10.1007/s11625-011-0149-x

Laurans, Y., Rankovic, A., Billé, R., Pirard, R., Mermet, L., 2013. Use of ecosystem services economic valuation for decision-making: Questioning a literature blindspot. J. Environ. Manage. 119, 208-219. https://doi.org/10.1016/j.jenvman.2013.01.008

Laurans, Y., Mermet, L., 2014. Ecosystem services economic valuation, decision-support system or advocacy? Ecosyst. Serv. 7, 98-105. https://doi.org/10.1016/j.ecoser.2013.10.002

Lautenbach, S., Mupepele, A.C., Dormann, C.F., Lee, H., Schmidt, S., Scholte, S.S.K., Seppelt, R., van Teeffelen, A.J.A., Verhagen, W., Volk, M., 2019. Blind spots in ecosystem services research and challenges for implementation. Reg. Environ. Chang. 19, 2151-2172. https://doi.org/10.1007/s10113-018-1457-9 
Levrel, H., Cabral, P., Feger, C., Chambolle, M., Basque, D., 2017. How to overcome the implementation gap in ecosystem services? A user-friendly and inclusive tool for improved urban management. Land use policy 68, 574-584.

https://doi.org/10.1016/j.landusepol.2017.07.037

Lienhoop, N., Macmillan, D.C., 2007. Valuing wilderness in Iceland: Estimation of WTA and WTP using the market stall approach to contingent valuation. Land use policy 24, 289-295. https://doi.org/10.1016/j.landusepol.2005.07.001

Lienhoop, N., Völker, M., 2016. Preference refinement in deliberative choice experiments. Land Econ. 92, 555-577. https://doi.org/10.3368/le.92.3.555

Lin, C.-F., 2013. Scientification of politics or politicization of science: reassessing the limits of international food safety lawmaking. Columbia Sci. Technol. Law Rev. 15, 1.

Liu, J., Li, S., Ouyang, Z., Tam, C., Chen, X., 2008. Ecological and socioeconomic effects of China's policies for ecosystem services. Proc. Natl. Acad. Sci. U. S. A. 105, 9477-9482. https://doi.org/10.1073/pnas.0706436105

Macmillan, D.C., Philip, L., Hanley, N., Alvarez-Farizo, B., 2002. Valuing the non-market benefits of wild goose conservation: a comparison of interview and group-based approaches. Ecol. Econ. 43, 49-59.

Maczka, K., Matczak, P., Pietrzyk-Kaszyńska, A., Rechciński, M., Olszańska, A., Cent, J., Grodzińska-Jurczak, M., 2016. Application of the ecosystem services concept in environmental policy-A systematic empirical analysis of national level policy documents in Poland. Ecol. Econ. 128, 169-176. https://doi.org/10.1016/j.ecolecon.2016.04.023

Maes, J., Hauck, J., Paracchini, M.L., Ratamäki, O., Hutchins, M., Termansen, M., Furman, E., Pérez-Soba, M., Braat, L., Bidoglio, G., 2013. Mainstreaming ecosystem services into EU policy. Curr. Opin. Environ. Sustain. 5, 128-134. https://doi.org/10.1016/j.cosust.2013.01.002

Marre, J.B., Billé, R., 2019. A demand-driven approach to ecosystem services economic valuation: Lessons from Pacific island countries and territories. Ecosyst. Serv. 39, 100975. https://doi.org/10.1016/j.ecoser.2019.100975

Martin, D.M., Mazzotta, M., 2018. Non-monetary valuation using Multi-Criteria Decision Analysis: Sensitivity of additive aggregation methods to scaling and compensation assumptions. Ecosyst. Serv. 29, 13-22. https://doi.org/10.1016/j.ecoser.2017.10.022

Martin-Ortega, J., Perni, A., Jackson-Blake, L., Balana, B.B., Mckee, A., Dunn, S., Helliwell, R., Psaltopoulos, D., Skuras, D., Cooksley, S., Slee, B., 2015. A transdisciplinary approach to the economic analysis of the European Water Framework Directive. Ecol. Econ. 116, 34-45. https://doi.org/10.1016/j.ecolecon.2015.03.026

Matland, R.E., 1995. Synthesizing the Implementation Literature: The Ambiguity-Conflict Model of Policy Implementation. J. Public Adm. Res. Theory 5, 145-174. 
Mauerhofer, V., 2017. Legal aspects of ecosystem services: An introduction and an overview. Ecosyst. Serv. https://doi.org/10.1016/j.ecoser.2017.11.002

Mauerhofer, V., Laza, I., 2017. How do ecosystem services perform in enforceable law? Potentials and pitfalls within regional and national integration. Ecosyst. Serv. 1-11. https://doi.org/10.1016/j.ecoser.2017.07.006

May, P.J., Winter, S.C., 2007. Politicians, Managers, and Street-Level Bureaucrats: Influences on Policy Implementation. J. Public Adm. Res. Theory 19, 453-476.

https://doi.org/10.1093/jopart/mum030

Mobjörk, M., 2010. Consulting versus participatory transdisciplinarity: A refined classification of transdisciplinary research. Futures 42, 866-873. https://doi.org/10.1016/j.futures.2010.03.003

Murphy, M.B., Mavrommati, G., Mallampalli, V.R., Howarth, R.B., Borsuk, M.E., 2017. Comparing group deliberation to other forms of preference aggregation in valuing ecosystem services. Ecol. Soc. 22. https://doi.org/10.5751/ES-09519-220417

Neßhöver, C., Timaeus, J., Wittmer, H., Krieg, A., Geamana, N., Van Den Hove, S., Young, J., Watt, A., 2013. Improving the science-policy interface of biodiversity research projects. Gaia 22, 99-103. https://doi.org/10.14512/gaia.22.2.8

Newbold, S., Simpson, R.D., Massey, D.M., Heberling, M.T., Wheeler, W., Corona, J., Hewitt, J., 2018. Benefit transfer challenges: a U.S. Environmental Protection Agency perspective. Environ. Resour. Econ. 69, 467-481. https://doi.org/10.1007/978-94-007-0753-5_100099

Newig, J., Koontz, T.M., 2014. Multi-level Governance, Policy Implementation and Participation: The EU's Mandated Participatory Planning Approach to Implementing Environmental Policy. J. Eur. Public Policy 21, 248-267.

Noe, R.R., Keeler, B.L., Kilgore, M.A., Taff, S.J., Polasky, S., 2017. Mainstreaming ecosystem services in state-level conservation planning: progress and future needs. Ecol. Soc. 22, art4. https://doi.org/10.5751/ES-09581-220404

Nordin, A.C., Hanson, H.I., Olsson, J.A., 2017. Integration of the ecosystem services concept in planning documents from six municipalities in southwestern Sweden. Ecol. Soc. 22.

Olander, L., Polasky, S., Kagan, J.S., Johnston, R.J., Wainger, L., Saah, D., Maguire, L., Boyd, J., Yoskowitz, D., 2017. So you want your research to be relevant? Building the bridge between ecosystem services research and practice. Ecosyst. Serv. 26, 170-182. https://doi.org/10.1016/j.ecoser.2017.06.003

O’Toole, L.J., 1986. Policy Recommendations for Multi-Actor Implementation: An Assessment of the Field. J. Public Policy 6, 181-210.

O'Toole, L.J., 2000. Research on Policy Implementation: Assessment and Prospects. J. Public Adm. Res. Theory 10, 263-288. 
Pasgaard, M., Van Hecken, G., Ehammer, A., Strange, N., 2017. Unfolding scientific expertise and security in the changing governance of Ecosystem Services. Geoforum 84, 354-367. https://doi.org/10.1016/j.geoforum.2017.02.001

Pérez-Soba, M., Verweij, P., Saarikoski, H., Harrison, P.A., Barton, D.N., Furman, E., 2018. Maximising the value of research on ecosystem services: Knowledge integration and guidance tools mediating the science, policy and practice interfaces. Ecosyst. Serv. 29, 599607. https://doi.org/10.1016/j.ecoser.2017.11.012

Philip, L.J., Macmillan, D.C., 2005. Exploring Values, Context and Perceptions in Contingent Valuation Studies: The CV Market Stall Technique and Willingness to Pay for Wildlife Conservation. J. Environ. Plan. Manag. 48, 257-274. https://doi.org/10.1080/0964056042000338172

Plummer, M.L., 2009. Assessing benefit transfer for the valuation of ecosystem services. Front. Ecol. Environ. 7, 38-45. https://doi.org/10.1890/080091

Polasky, S., Tallis, H., Reyers, B., 2015. Setting the bar: Standards for ecosystem services. Proc. Natl. Acad. Sci. 112, 7356-7361. https://doi.org/10.1073/pnas.1406490112

Poljanec-Borić, S., Wertag, A., Caric, H., 2018. The Perception of Ecosystem Services in Public Sector Domains of Health, Tourism and Environment Protection in Croatia. Sociol. i Prost. 574, 119-136. https://doi.org/10.5673/sip.56.2.2

Posner, S.M., McKenzie, E., Ricketts, T.H., 2016a. Policy impacts of ecosystem services knowledge. Proc. Natl. Acad. Sci. 113, 1760-1765. https://doi.org/10.1073/pnas.1502452113

Posner, S., Getz, C., Ricketts, T., 2016b. Evaluating the impact of ecosystem service assessments on decision-makers. Environ. Sci. Policy 64, 30-37. https://doi.org/10.1016/j.envsci.2016.06.003

Potschin, M., Haines-Young, R., 2016. Conceptual Frameworks and the Cascade Model, in: OpenNESS Ecosystem Services Reference Book. EC FP7 Grant Agreement No. 308428. pp. $1-6$.

Potschin-Young, M., Czúcz, B., Liquete, C., Maes, J., Rusch, G.M., Haines-Young, R., 2017. Intermediate ecosystem services: An empty concept? Ecosyst. Serv. 27, 124-126. https://doi.org/10.1016/j.ecoser.2017.09.001

Povitkina, M., 2015. Democracy, Bureaucratic Capacity and Environmental Performance (No. 2015:13), Working Paper Series.

Raum, S., 2018. Reasons for Adoption and Advocacy of the Ecosystem Services Concept in UK Forestry. Ecol. Econ. 143, 47-54. https://doi.org/10.1016/j.ecolecon.2017.07.001

Rauschmayer, F., Wittmer, H., 2006. Evaluating deliberative and analytical methods for the resolution of environmental conflicts. Land use policy 23, 108-122.

https://doi.org/10.1016/j.landusepol.2004.08.011 
Raymond, C.M., Kenter, J.O., Plieninger, T., Turner, N.J., Alexander, K.A., 2014. Comparing instrumental and deliberative paradigms underpinning the assessment of social values for cultural ecosystem services. Ecol. Econ. 107, 145-156.

Reed, M.S., 2008. Stakeholder participation for environmental management: A literature review. Biol. Conserv. 141, 2417-2431. https://doi.org/10.1016/j.biocon.2008.07.014

Richardson, L., Loomis, J., Kroeger, T., Casey, F., 2015. The role of benefit transfer in ecosystem service valuation. Ecol. Econ. 115, 51-58. https://doi.org/10.1016/j.ecolecon.2014.02.018

Roggero, M., 2013. Shifting Troubles: Decision-Making versus Implementation in Participatory Watershed Governance. Environ. Policy Gov. 23, 63-74. https://doi.org/10.1002/eet.1603

Rosenthal, A., Verutes, G., McKenzie, E., Arkema, K.K., Bhagabati, N., Bremer, L.L., Olwero, N., Vogl, A.L., 2015. Process matters: A framework for conducting decision-relevant assessments of ecosystem services. Int. J. Biodivers. Sci. Ecosyst. Serv. Manag. 11, 190-204. https://doi.org/10.1080/21513732.2014.966149

Rowe, G., Frewer, L.J., 2005. A Typology of Public Engagement Mechanisms. Sci. Technol. Hum. Values 30, 251-290. https://doi.org/10.1177/0162243904271724

Rozas-Vásquez, D., Fürst, C., Geneletti, D., Almendra, O., 2018. Integration of ecosystem services in strategic environmental assessment across spatial planning scales. Land use policy 71, 303-310. https://doi.org/10.1016/j.landusepol.2017.12.015

Ruckelshaus, M., McKenzie, E., Tallis, H., Guerry, A.D., Daily, G., Kareiva, P., Polasky, S., Ricketts, T., Bhagabati, N., Wood, S.A., Bernhardt, J., 2015. Notes from the field: Lessons learned from using ecosystem service approaches to inform real-world decisions. Ecol. Econ. 115, 11-21. https://doi.org/10.1016/j.ecolecon.2013.07.009

Sabatier, P.A., 1986. Top-Down and Bottom-Up Approaches to Implementation Research: A Critical Analysis and Suggested Synthesis. J. Public Policy 6, 21.

https://doi.org/10.1017/S0143814X00003846

Saetren, H., 2005. Facts and myths about research on public policy implementation: Out-offashion, allegedly dead, but still very much alive and relevant. Policy Stud. J. 33, 559-582. https://doi.org/10.1111/j.1541-0072.2005.00133.x

Salles, J.M., 2011. Valuing Biodiversity and Ecosystem Services: Why linking economic value with nature? (No. 2011-24), LAMETA - Documents de recherche.

Sarkki, S., Niemelä, J., Tinch, R., van den Hove, S., Watt, A., Young, J., 2014. Balancing credibility, relevance and legitimacy: A critical assessment of trade-offs in science-policy interfaces. Sci. Public Policy 41, 194-206. https://doi.org/10.1093/scipol/sct046

Schirpke, U., Marino, D., Marucci, A., Palmieri, M., Scolozzi, R., 2017. Operationalising ecosystem services for effective management of protected areas: Experiences and challenges. Ecosyst. Serv. 28, 105-114. https://doi.org/10.1016/j.ecoser.2017.10.009 
Seppelt, R., Dormann, C.F., Eppink, F. V., Lautenbach, S., Schmidt, S., 2011. A quantitative review of ecosystem service studies: Approaches, shortcomings and the road ahead. J. Appl. Ecol. 48, 630-636. https://doi.org/10.1111/j.1365-2664.2010.01952.x

Shahar, D.C., 2015. Rejecting Eco-Authoritarianism, Again. Environ. Values.

Sharon, O., Fishman, S.N., Ruhl, J.B., Olander, L., Roady, S.E., 2018. Ecosystem services and judge-made law: A review of legal cases in common law countries. Ecosyst. Serv. 32, 9-21. https://doi.org/10.1016/j.ecoser.2018.05.010

Sowers, J., 2007. Nature Reserves and Authoritarian Rule in Egypt: Embedded Autonomy Revisited. J. Environ. Dev. 16, 375-397. https://doi.org/10.1177/1070496507309112

Spangenberg, J.H., Settele, J., 2010. Precisely incorrect? Monetising the value of ecosystem services. Ecol. Complex. 7, 327-337. https://doi.org/10.1016/j.ecocom.2010.04.007

Spash, C.L., Vatn, A., 2006. Transferring environmental value estimates: Issues and alternatives. Ecol. Econ. 60, 379-388. https://doi.org/10.1016/j.ecolecon.2006.06.010

Spash, C.L., 2007. Deliberative monetary valuation (DMV): Issues in combining economic and political processes to value environmental change. Ecol. Econ. 63, 690-699. https://doi.org/10.1016/j.ecolecon.2007.02.014

Steger, C., Hirsch, S., Evers, C., Branoff, B., Petrova, M., Nielsen-Pincus, M., Wardropper, C., van Riper, C.J., 2018. Ecosystem Services as Boundary Objects for Transdisciplinary Collaboration. Ecol. Econ. 143, 153-160. https://doi.org/10.1016/j.ecolecon.2017.07.016

Stringer, L.C., Reed, M.S., Dougill, A.J., Seely, M.K., Rokitzki, M., 2007. Implementing the UNCCD: Participatory challenges. Nat. Resour. Forum 31, 198-211. https://doi.org/10.1111/j.14778947.2007.00154.x

Studley, J., Bleisch, W. V., 2018. Juristic personhood for sacred natural sites: A potential means for protecting nature. Parks 24, 81-96. https://doi.org/10.2305/IUCN.CH.2018.PARKS-241JS.en

Su, M., Peng, B., 2018. Integrating values of ecosystem services into decision-making in coastal management in Xiamen. Ocean Coast. Manag. 104590.

https://doi.org/10.1016/j.ocecoaman.2018.08.024

Szabó, Z., 2011. Reducing protest responses by deliberative monetary valuation: Improving the validity of biodiversity valuation. Ecol. Econ. 72, 37-44. https://doi.org/10.1016/j.ecolecon.2011.09.025

TEEB, 2010. Teeb - The Economics of Ecosystem and Biodiversity for local and regional policymakers. Report 207.

Teixeira da Silva, R., Fleskens, L., van Delden, H., van der Ploeg, M., 2018. Incorporating soil ecosystem services into urban planning: status, challenges and opportunities. Landsc. Ecol. 33, 1087-1102. https://doi.org/10.1007/s10980-018-0652-x 
Thompson Klein, J., 2004. Prospects for transdisciplinarity. Futures 36, 515-526. https://doi.org/10.1016/j.futures.2003.10.007

Tisdell, C., 2014. Ecosystems functions and genetic diversity: TEEB raises challenges for the economics discipline. Econ. Anal. Policy 44, 14-20.

https://doi.org/10.1016/j.eap.2014.02.004

Tress, G., Tress, B., Fry, G., 2005. Clarifying integrative research concepts in landscape ecology. Landsc. Ecol. 20, 479-493. https://doi.org/10.1007/s10980-004-3290-4

van den Hove, S., 2007. A rationale for science-policy interfaces. Futures 39, 807-826. https://doi.org/10.1016/j.futures.2006.12.004

van Oudenhoven, A.P.E., Aukes, E., Bontje, L.E., Vikolainen, V., van Bodegom, P.M., Slinger, J.H., 2018. 'Mind the Gap' between ecosystem services classification and strategic decisionmaking. Ecosyst. Serv. 33, 77-88. https://doi.org/10.1016/j.ecoser.2018.09.003

Völker, M., Lienhoop, N., 2016. Exploring group dynamics in deliberative choice experiments. Ecol. Econ. 123, 57-67. https://doi.org/10.1016/j.ecolecon.2016.01.006

Watson, R.T., 2005. Turning science into policy: challenges and experiences from the sciencepolicy interface. Philos. Trans. R. Soc. B Biol. Sci. 360, 471-477.

https://doi.org/10.1098/rstb.2004.1601

Wegner, G., Pascual, U., 2011. Cost-benefit analysis in the context of ecosystem services for human well-being: A multidisciplinary critique. Glob. Environ. Chang. 21, 492-504. https://doi.org/10.1016/j.gloenvcha.2010.12.008

Wright, W.C.C., Eppink, F. V., Greenhalgh, S., 2017. Are ecosystem service studies presenting the right information for decision-making? Ecosyst. Serv. 25, 128-139.

https://doi.org/10.1016/j.ecoser.2017.03.002

Young, J.C., Waylen, K.A., Sarkki, S., Albon, S., Bainbridge, I., Balian, E., Davidson, J., Edwards, D., Fairley, R., Margerison, C., McCracken, D., Owen, R., Quine, C.P., Stewart-Roper, C., Thompson, D., Tinch, R., van den Hove, S., Watt, A., 2014. Improving the science-policy dialogue to meet the challenges of biodiversity conservation: Having conversations rather than talking at one-another. Biodivers. Conserv. 23, 387-404.

https://doi.org/10.1007/s10531-013-0607-0

Zhang, Z., Sherman, R., Yang, Z., Wu, R., Wang, W., Yin, M., Yang, G., Ou, X., 2013. Integrating a participatory process with a GIS-based multi-criteria decision analysis for protected area zoning in China. J. Nat. Conserv. 21, 225-240. https://doi.org/10.1016/j.jnc.2012.12.006 